\title{
Regional Antarctic snow accumulation over the past 1000 years
}

\author{
Elizabeth R. Thomas ${ }^{1}$, J. Melchior van Wessem ${ }^{2}$, Jason Roberts ${ }^{3,4}$, Elisabeth Isaksson ${ }^{5}$, Elisabeth Schlosser ${ }^{6,7}$, \\ Tyler J. Fudge ${ }^{8}$, Paul Vallelonga ${ }^{9}$, Brooke Medley ${ }^{10}$, Jan Lenaerts ${ }^{2}$, Nancy Bertler ${ }^{11,12}$, Michiel R. van den Broeke ${ }^{2}$, \\ Daniel A. Dixon ${ }^{13}$, Massimo Frezzotti ${ }^{14}$, Barbara Stenni ${ }^{15,16}$, Mark Curran ${ }^{3}$, and Alexey A. Ekaykin ${ }^{17,18}$ \\ ${ }^{1}$ Ice Dynamics and Paleoclimate, British Antarctic Survey, Cambridge, UK CB3 OET \\ ${ }^{2}$ Institute for Marine and Atmospheric Research Utrecht (IMAU), Utrecht University, Utrecht, the Netherlands \\ ${ }^{3}$ Antarctic Climate and Ecosystems, Australian Antarctic Division, Hobart, Tasmania 7050, Australia \\ ${ }^{4}$ Antarctic Climate \& Ecosystems Cooperative Research Centre, University of Tasmania, Hobart, 7001, Australia \\ ${ }^{5}$ Geology and Geophysics, Norwegian Polar Institute, 9296 Troms $\varnothing$, Norway \\ ${ }^{6}$ Institute of Atmospheric and Cryospheric Sciences, Austrian Polar Research Institute, Vienna, Austria \\ ${ }^{7}$ Institute of Atmospheric and Cryospheric Sciences, University of Innsbruck, Innsbruck, Austria \\ ${ }^{8}$ Earth and Space Sciences, University of Washington, Seattle, USA \\ ${ }^{9}$ Centre for Ice and Climate, Niels Bohr Institute, University of Copenhagen, Copenhagen, Denmark \\ ${ }^{10}$ Cryospheric Sciences Laboratory, NASA Goddard Space Flight Center, Greenbelt, Maryland, USA \\ ${ }^{11}$ Antarctic Research Centre, Victoria University, Wellington 6012, New Zealand \\ ${ }^{12}$ National Ice Core Research Laboratory, GNS Science, Lower Hutt 5040, New Zealand \\ ${ }^{13}$ Climate Change Institute, University of Maine, Orono, Maine 04469, USA \\ ${ }^{14}$ ENEA, Agenzia Nazionale per le nuove tecnologie, l'energia e lo sviluppo sostenibile, Rome, Italy \\ ${ }^{15}$ Department of Environmental Sciences, Informatics and Statistics, Ca' Foscari University of Venice, Venice, Italy \\ ${ }^{16}$ Institute for the Dynamics of Environmental Processes, CNR, Venice, Italy \\ ${ }^{17}$ Climate and Environmental Research Laboratory, Arctic and Antarctic Research Institute, St. Petersburg, 199397, Russia \\ ${ }^{18}$ Institute of Earth Sciences, Saint Petersburg State University, St. Petersburg, 199178, Russia
}

Correspondence to: Elizabeth R. Thomas (lith@bas.ac.uk)

Received: 13 February 2017 - Discussion started: 28 March 2017

Revised: 25 August 2017 - Accepted: 20 September 2017 - Published: 10 November 2017

\begin{abstract}
Here we present Antarctic snow accumulation variability at the regional scale over the past 1000 years. A total of 79 ice core snow accumulation records were gathered and assigned to seven geographical regions, separating the high-accumulation coastal zones below $2000 \mathrm{~m}$ of elevation from the dry central Antarctic Plateau. The regional composites of annual snow accumulation were evaluated against modelled surface mass balance (SMB) from RACMO2.3p2 and precipitation from ERA-Interim reanalysis. With the exception of the Weddell Sea coast, the low-elevation composites capture the regional precipitation and SMB variability as defined by the models. The central Antarctic sites lack coherency and either do not represent regional precipitation or indicate the model inability to capture relevant precipitation processes in the cold, dry central plateau. Our results show that SMB for the total Antarctic Ice Sheet (including
\end{abstract}

ice shelves) has increased at a rate of $7 \pm 0.13 \mathrm{Gt} \mathrm{decade}^{-1}$ since $1800 \mathrm{AD}$, representing a net reduction in sea level of $\sim 0.02 \mathrm{~mm} \mathrm{decade}^{-1}$ since 1800 and $\sim 0.04 \mathrm{~mm} \mathrm{decade}^{-1}$ since $1900 \mathrm{AD}$. The largest contribution is from the Antarctic Peninsula $(\sim 75 \%)$ where the annual average SMB during the most recent decade (2001-2010) is $123 \pm 44 \mathrm{Gt} \mathrm{yr}^{-1}$ higher than the annual average during the first decade of the 19th century. Only four ice core records cover the full 1000 years, and they suggest a decrease in snow accumulation during this period. However, our study emphasizes the importance of low-elevation coastal zones, which have been under-represented in previous investigations of temporal snow accumulation. 


\section{Introduction}

The Antarctic Ice Sheet (AIS) is the largest reservoir of fresh water on the planet and has the potential to raise global sea level by about $58.3 \mathrm{~m}$ if melted completely (IPCC, 2013). Even small changes in its volume could have significant impacts, not just on global mean sea level, but also on the wider hydrological cycle, atmospheric circulation, sea surface temperature, ocean salinity, and thermohaline circulation. The mass balance of the AIS constitutes the difference between mass gains, mainly by snow accumulation, and mass losses, mainly by ice flow over the grounding line. Ice sheet mass balance is currently estimated in three ways: (1) ice sheet volume change is calculated using repeated surface elevation measurements from radar or laser altimeters on airborne or spaceborne platforms followed by a conversion from volume change to mass change using a model for firn density. (2) Ice sheet mass changes can be directly measured using the Gravity Recovery and Climate Experiment (GRACE) satellite system. (3) Surface mass balance (SMB) and solid ice discharge can be individually estimated and subtracted (Rignot et al., 2011). These three techniques have significantly advanced our understanding of contemporary AIS mass balance, with growing evidence of increased mass loss over recent decades (Velicogna and Wahr, 2006; Allison et al., 2009; Chen et al., 2009; Rignot et al., 2011; Shepherd et al., 2012). However, the uncertainties in these assessments may be as high as $75 \%$ (Shepherd et al., 2012), and another study even suggested a positive trend over the same period (Zwally et al., 2015).

The discrepancies and uncertainties may in part reflect the large interannual (Wouters et al., 2013) and spatial (Anschütz et al., 2006) variability in snowfall and hence SMB, but also the difficulty with which SMB is measured and the complexities of the data interpretation. AIS SMB is the net result of multiple processes such as surface mass gains from snowfall and deposition and losses from snow sublimation and wind erosion. Mass losses from meltwater runoff are small in Antarctica, except for some parts of the Antarctic Peninsula. Multiple in situ SMB observations can be combined to produce an SMB map for selected ice sheet regions (Rotschky et al., 2007) or for the entire AIS (Favier et al., 2013). Alternatively, SMB can be simulated by (regional) atmospheric climate models, such as the Regional Atmospheric Climate Model (RACMO) version 2.3 (Van Wessem et al., 2014), and various reanalysis products such as ERA-Interim (Dee et al., 2001) or JRA55 (Kobayashi et al., 2015). Estimates of SMB can be improved by combining methods following, for example, the approach of Arthern et al. (2006) by interpolating field measurements with remotely sensed data as a background field or Van de Berg et al. (2006), who fitted output from a regional model to in situ observations. The resulting values of SMB averaged over the grounded AIS range from $143 \mathrm{~kg} \mathrm{~m}^{-2} \mathrm{yr}^{-1}$ (Arthern et al., 2006) to $168 \mathrm{~kg} \mathrm{~m}^{-2} \mathrm{yr}^{-1}$ (van de Berg et al., 2006). Several studies have evaluated modelled SMB with in situ observations across Antarctica (Thomas and Bracegirdle, 2009, 2015; Agosta et al., 2012; Sinisalo et al., 2013; Medley et al., 2013 and Wang et al., 2015). Finally, the resulting maps of SMB can be combined with estimates of dynamical mass loss to estimate regional or continental ice sheet mass balance.

An increase in Antarctic SMB is expected in a warmer climate as a result of increased precipitation when atmospheric moisture content increases (Krinner et al., 2007; Agosta et al., 2012; Ligtenberg et al., 2013; Frieler et al., 2015), with climate models on average predicting a $7.4 \%$ precipitation increase per degree of atmospheric warming (Palerme et al., 2017). This potentially results in a mitigation of sea level rise in the future (Krinner et al., 2007; Agosta et al., 2012) ranging from 25 to $85 \mathrm{~mm}$ during the $21 \mathrm{st}$ century, depending on the climate scenario (Palerme et al., 2017). However, almost all of the models in the Fifth Climate Model Intercomparison Project (CMIP5) overestimate Antarctic precipitation (Palerme et al., 2017).

In order to better constrain predictions of future contributions to global sea level, it is therefore of vital importance to gain a thorough understanding of past and present changes in SMB and its relationship with the climate system. Whereas the methods discussed above are invaluable in determining contemporary SMB and its spatial variability, only ice core records have the ability to investigate past SMB beyond the instrumental and satellite period. Previous studies have evaluated ice core records to reveal an insignificant change in Antarctic accumulation rates since the 1950s (Monaghan et al., 2006a, b), and Frezzotti et al. (2013) extended this analysis to conclude that the current SMB is not exceptionally high in the context of the past 800 years.

However, in recent years the number of ice core accumulation records has increased, revealing large differences in the spatial pattern of snow accumulation and trends. Ice core records from the Antarctic Peninsula (AP) show dramatic increases in snowfall during the 20th century (Thomas et al., 2008; Goodwin et al., 2016), which appear unusual in the context of the past $\sim 300$ years (Thomas et al., 2015). In Dronning Maud Land (DML), similarly large increases in precipitation have been observed in an ice core from a coastal ice rise (Philippe et al., 2016), consistent with remotely sensed estimates of recent mass gain (Shepherd et al., 2012). However, other coastal cores in DML exhibit a decrease in SMB in recent decades (Altnau et al., 2015; Schlosser et al., 2014; Sinisalo et al., 2013), despite evidence of several high-accumulation years since 2009 related to a persistent atmospheric blocking flow pattern (Lenaerts et al., 2013; Schlosser et al., 2016). In Wilkes Land, the Law Dome ice core record reveals similarly elevated accumulation during the most recent 30 years but also periods of elevated snowfall $\sim 1600$ and $\sim 1200$ years ago (Roberts et al., 2015). The growing evidence for large regional differences in snow accumulation trends demonstrates the need for a regionally 
focused study of snow accumulation beyond the instrumental period.

Here we compile all the available Antarctic ice core snow accumulation records as part of the PAGES (Past Global Changes) Antarctica 2k working group, an initiative of the Future Earth research platform. The aim is to improve regional estimates of SMB variability using well-constrained and quality-checked snow accumulation records from ice cores. We will assess the regional representativeness of ice core snow accumulation composites and the spatial pattern of variability by utilizing precipitation data derived from reanalysis products and SMB from the RACMO2.3p2 regional climate model. We review the dominant atmospheric drivers of regional SMB, evaluate the changes over centennial timescales, and place these changes in the context of the past 1000 years.

\section{Data and methods}

\subsection{Snow accumulation from ice cores}

Ice cores have the potential to record the amount of snow accumulation at a specific location over a range of timescales. Barring post-depositional processes, the recorded snow accumulation is the net result of solid precipitation, sublimation, wind erosion or deposition, and meltwater runoff. Integrated over the AIS the contributions made by sublimation or deposition, wind redistribution, rainfall, and meltwater runoff are relatively small (van Wessem et al., 2014) and therefore the dominant component of Antarctic SMB is solid precipitation. Locally, however, drifting snow erosion or deposition and sublimation may play an important role, especially in regions of strong katabatic flow (Lenaerts and Van den Broeke, 2012).

\subsection{Calculating snow accumulation and correcting for thinning and flow}

Estimates of snow accumulation are based on the physical distance between suitable age markers within the ice core, corrected for firn density and the integrated influence of the vertical strain rate profile (so-called "layer thinning"). Depending on the timescale of interest, age markers may include bulk changes in isotopic composition reflecting glacial cycles, volcanic eruptions for decadal to millennial timescales, seasonal variations in stable water isotopes, and chemical species including sea salts, hydrogen peroxide, radio isotopes, and biologically controlled compounds (Dansgaard and Johnsen, 1969). Once suitable age markers have been identified, the effects of firn density can be corrected for by convolving the physical depth in the ice core $\left(z^{\prime}\right)$ by the density as a function of depth $\left(\rho\left(z^{\prime}\right)\right)$ as a fraction of a reference density $\left(\rho_{\text {ref }}\right)$ to give an equivalent depth $(z)$ :

$z=\frac{1}{\rho_{\text {ref }}} \int_{\text {surface }}^{z^{\prime}} \rho(y) \mathrm{d} y$.

Typically, the reference density is either the density of glacial ice (resulting in "ice equivalent" measurements) or taken as $1000 \mathrm{~kg} \mathrm{~m}^{-3}$ to give "water equivalent" (w.e) results.

Finally, due to the differential vertical velocity with depth (the vertical strain rate), the distance between layers at the surface will decrease with depth. If the profile of vertical strain rate with depth is known and is assumed to be invariant over time, then it can be corrected for. However, the vertical stain rate is typically unknown. In the absence of any other data, the vertical strain rate profile can be approximated as a constant (Nye, 1963), which in general is applicable in the upper portion of the ice sheet. Further refinement to this approximation was suggested by Dansgaard and Johnsen (1969) who proposed a piecewise linear vertical strain rate profile, constant in the upper portion of the ice sheet and below that decreasing linearly to zero at the base of the ice sheet, or a non-zero value in the presence of basal melt.

Roberts et al. (2015) show that a more realistic vertical strain rate profile, based on the power-law distribution of horizontal velocity of Lliboutry (1979), may provide a better estimate of strain rate even in the upper portion of the ice sheet. Additionally, recently deployed ground-based phasesensitive ice-penetrating radar systems have demonstrated the ability to measure the vertical strain rate profile (Nicholls et al., 2015).

Uncertainties in the accumulation rate associated with the vertical strain increase with depth. Most of the ice cores in this study are relatively shallow, and therefore uncertainty in the vertical strain rate is expected to be low. Roberts et al. (2015) found the influence of the vertical strain rate model to be concentrated at lower frequency and to be small (less than $4 \%$ of the accumulation rate).

\subsection{Antarctica $2 \mathrm{k}$ snow accumulation database}

The criteria for this study were that all ice-core-derived snow accumulation records must be published, peer reviewed, and have an annual resolution. Each record must cover at least the reference period (1960-1990) and have demonstrated that reference horizons (such as volcanic markers) were used to constrain the dating. Published dating errors range from $1-$ 3 years for the period 1800-2010, increasing to $\sim 5$ years for some sites prior to $\sim 1500 \mathrm{AD}$. The published thinning function was applied to each record (from one of those described above), as this is assumed to be the most suitable for the individual site.

From a total of 144 records submitted to the Antarctica 2k database, 79 records were eligible for this study (Table 1), 
Table 1. Ice core data used in this study. Data citations can be found in Table S1 and in Thomas (2017).

\begin{tabular}{|c|c|c|c|c|c|}
\hline Site name & Latitude & Longitude & Elevation (m) & Years AD & Reference \\
\hline \multicolumn{6}{|l|}{ 1. East Antarctic Plateau } \\
\hline Vostok composite VRS13 & -78.47 & 106.83 & 3488 & $1654-2010$ & Ekaykin et al. (2014) \\
\hline B31Site DML07 & -75.58 & -3.43 & 2680 & $1025-1990$ & $\begin{array}{l}\text { Sommer et al. (2000), } \\
\text { Oerter et al. (2000) }\end{array}$ \\
\hline B32Site DML05 & -75 & -0.01 & 2882 & $1025-1990$ & $\begin{array}{l}\text { Sommer et al. (2000), } \\
\text { Oerter et al. (2000) }\end{array}$ \\
\hline B33Site DML17 & -75.17 & 6.5 & 3160 & $1025-1990$ & $\begin{array}{l}\text { Sommer et al. (2000), } \\
\text { Oerter et al. (2000) }\end{array}$ \\
\hline FB96DML01 & -74.86 & -2.55 & 2817 & $1895-1995$ & Oerter et al. (1999) \\
\hline FB96DML02 & -74.97 & -3.92 & 3014 & 1919-1995 & Oerter et al. (1999) \\
\hline FB96DML03 & -74.49 & 1.96 & 2843 & 1941-1996 & Oerter et al. (1999) \\
\hline FB96DML04 & -74.40 & 7.21 & 3161 & 1905-1996 & Oerter et al. (1999) \\
\hline FB96DML05 & -75.00 & 0.012 & 2882 & 1930-1996 & Oerter et al. (1999) \\
\hline FB96DML06 & -75.01 & 8.01 & 3246 & 1899-1996 & Oerter et al. (1999) \\
\hline FB96DML07 & -74.59 & -3.439 & 2669 & 1908-1996 & Oerter et al. (1999) \\
\hline FB96DML08 & -75.75 & 3.2936 & 2962 & 1919-1996 & Oerter et al. (1999) \\
\hline FB96DML09 & -75.93 & 7.2217 & 3145 & 1897-1996 & Oerter et al. (1999) \\
\hline FB96DML10 & -75.22 & 11.35 & 3349 & 1900-1996 & Oerter et al. (1999) \\
\hline FB9803 & -74.85 & -8.497 & 2600 & 1921-1997 & Oerter et al. (2000) \\
\hline FB9804 & -75.25 & -6.0 & 2630 & 1801-1996 & Oerter et al. (2000) \\
\hline FB9805 & -75.16 & -0.99 & 2840 & 1800-1996 & Oerter et al. (2000) \\
\hline FB9807 & -74.99 & 0.036 & 2880 & $1758-1996$ & Oerter et al. (2000) \\
\hline FB9808 & -74.75 & 0.999 & 2860 & 1801-1996 & Oerter et al. (2000) \\
\hline FB9809 & -74.49 & 1.960 & 2843 & 1801-1996 & Oerter et al. (2000) \\
\hline FB9810 & -74.67 & 4.001 & 2980 & $1801-1996$ & Oerter et al. (2000) \\
\hline FB9811 & -75.08 & 6.5 & 3160 & $1801-1996$ & Oerter et al. (2000) \\
\hline FB9812 & -75.25 & 6.502 & 3160 & 1810-1996 & Oerter et al. (2000) \\
\hline FB9813 & -75.17 & 5.00 & 3100 & 1800-1996 & Oerter et al. (2000) \\
\hline FB9814 & -75.08 & 2.50 & 2970 & $1801-1996$ & Oerter et al. (2000) \\
\hline FB9815 & -74.95 & -1.50 & 2840 & $1801-1996$ & Oerter et al. (2000) \\
\hline FB9816 & -75 & -4.50 & 2740 & 1800-1996 & Oerter et al. (2000) \\
\hline FB9817 & -75.00 & -6.50 & 2680 & 1800-1996 & Oerter et al. (2000) \\
\hline South Pole 1995 & -90 & 0 & 2850 & $1801-1991$ & Mosley-Thompson et al. (1999) \\
\hline GV2 & -71.71 & 145.26 & 2143 & $1670-2003$ & Frezzotti et al. (2013) \\
\hline D66 & -68.94 & 136.94 & 2333 & $1864-2003$ & Frezzotti et al. (2013) \\
\hline LGB65 & -71.85 & 77.92 & 1850 & $1745-1996$ & Xiao et al. (2004) \\
\hline US-ITASE-2002-7 & -88.99 & 59.97 & 3000 & 1900-2002 & Mayewski and Dixon (2013) \\
\hline US-ITASE-2002-4 & -86.5 & -107.99 & 2586 & $1594-2003$ & Mayewski and Dixon (2013) \\
\hline \multicolumn{6}{|l|}{ 2. Wilkes Land coast } \\
\hline DSS Law Dome & -66.77 & 112.81 & 1370 & 0-1995 & Roberts et al. (2015) \\
\hline 105 th $\mathrm{km}$ & -67.43 & 93.38 & 1407 & $1757-1987$ & Ekaykin et al. (2017) \\
\hline 200th km & -68.25 & 94.08 & 1990 & $1640-1988$ & Ekaykin et al. (2017) \\
\hline \multicolumn{6}{|l|}{ 3. Weddell Sea coast } \\
\hline Berkner Island (south) & -79.57 & -45.72 & 890 & $1000-1992$ & Mulvaney et al. (2002) \\
\hline \multicolumn{6}{|l|}{ 4. Antarctic Peninsula } \\
\hline Gomez & -73.59 & -70.36 & 1400 & $1858-2006$ & Thomas et al. (2008) \\
\hline James Ross Island & -64.22 & -57.68 & 1640 & $1832-1997$ & Aristarain et al. (2004) \\
\hline Dyer Plateau & -70.68 & -64.87 & 2002 & $1505-1988$ & Thompson et al. (1994) \\
\hline Bruce Plateau & -66.04 & -64.08 & 1976 & 1900-2009 & Goodwin et al. (2016) \\
\hline Beethoven & -71.9 & 74.6 & 580 & 1949-1991 & Pasteur and Mulvaney (2000) \\
\hline Ferrigno & -74.57 & -86.9 & 1354 & $1703-2010$ & Thomas et al. (2015) \\
\hline Bryan Coast & -74.50 & -81.68 & 1177 & $1712-2010$ & Thomas et al. (2015) \\
\hline
\end{tabular}


Table 1. Continued.

\begin{tabular}{|c|c|c|c|c|c|}
\hline Site name & Latitude & Longitude & Elevation (m) & Years AD & Reference \\
\hline \multicolumn{6}{|l|}{ 5. West Antarctic Ice Sheet } \\
\hline DIV2010 & -76.77 & -101.74 & 1330 & $1786-2010$ & Medley et al. (2013) \\
\hline THW2010 & -76.95 & -121.22 & 2020 & $1867-2010$ & Medley et al. (2013) \\
\hline PIG2010 & -77.96 & -95.96 & 1590 & $1918-2010$ & Medley et al. (2013) \\
\hline WDC05A & -79.46 & -112.09 & 1806 & $1775-2005$ & Banta et al. (2008) \\
\hline WD05Q & -79.46 & -112.09 & 1759 & $1522-2005$ & Banta et al. (2008) \\
\hline WAIS 2014 & -79.46 & -112.09 & 1759 & 0-2006 & Fudge et al. (2016) \\
\hline CWA-A & -82.36 & -119.286 & 950 & $1939-1993$ & Reusch et al. (1999) \\
\hline CWA-D & -81.37 & -107.275 & 1930 & $1952-1993$ & Reusch et al. (1999) \\
\hline Siple Dome-94 & -81.65 & -148.79 & 620 & 1891-1994 & Kaspari et al. (2004) \\
\hline Upstream-C (UP-C) & -82.44 & -135.97 & 525 & 1870-1996 & Kaspari et al. (2004) \\
\hline Ross ice drainage system A & -78.73 & -116.33 & 1740 & $1831-1995$ & Kaspari et al. (2004) \\
\hline Ross ice drainage system B & -79.46 & -118.05 & 1603 & 1922-1995 & Kaspari et al. (2004) \\
\hline Ross ice drainage system C & -80.01 & -119.43 & 1530 & 1903-1995 & Kaspari et al. (2004) \\
\hline US-ITASE-1999-1 & -80.62 & -122.63 & 1350 & $1724-2000$ & Kaspari et al. (2004) \\
\hline US-ITASE-2000-1 & -79.38 & -111.24 & 1791 & $1673-2001$ & Kaspari et al. (2004) \\
\hline US-ITASE-2000-3 & -78.43 & -111.92 & 1742 & $1971-2001$ & Mayewski and Dixon (2013) \\
\hline US-ITASE-2000-4 & -78.08 & -120.08 & 1697 & $1798-2000$ & Kaspari et al. (2004) \\
\hline US-ITASE-2000-5 & -77.68 & -123.99 & 1828 & 1718-1999 & Kaspari et al. (2004) \\
\hline US-ITASE-2001-1 & -79.16 & -104.97 & 1842 & 1986-2002 & Mayewski and Dixon (2013) \\
\hline US-ITASE-2001-2 & -82.00 & -110.01 & 1746 & $1892-2002$ & Kaspari et al. (2004) \\
\hline US-ITASE-2001-3 & -78.12 & -95.65 & 1620 & $1858-2002$ & Kaspari et al. (2004) \\
\hline US-ITASE-2001-4 & -77.61 & -92.24 & 1483 & 1986-2001 & Mayewski and Dixon (2013) \\
\hline US-ITASE-2001-5 & -77.06 & -89.14 & 1239 & 1780-2002 & Kaspari et al. (2004) \\
\hline \multicolumn{6}{|l|}{ 6. Victoria Land } \\
\hline Hercules Névé & -73.1 & 165.4 & 2960 & $1770-1992$ & Stenni et al. (1999) \\
\hline TD96 Talos Dome & -72.77 & 159.08 & 2316 & $1232-1995$ & Stenni et al. (2002) \\
\hline GV7 & -70.68 & 158.86 & 1947 & 1854-2004 & Frezzotti et al. $(2007,2013)$ \\
\hline GV5 & -71.89 & 158.54 & 2184 & 1777-2004 & Frezzotti et al. $(2007,2013)$ \\
\hline RICE & -79.36 & 161.64 & 560 & 0-2012 & Winstrup et al. (2017) \\
\hline \multicolumn{6}{|l|}{ 7. Dronning Maud Land } \\
\hline Fimbulisen S20 & -70.25 & 4.82 & 63 & $1956-1996$ & Isaksson et al. (1999) \\
\hline Fimbulisen S100 & -70.24 & 4.8 & 48 & 1737-1999 & Kaczmarska et al. (2004) \\
\hline Georg von Neumayer (B04) & -70.62 & -8.37 & 28 & $1892-1981$ & Schlosser (1999) \\
\hline Kottas Camp FB9802 & -74.21 & -9.75 & 1439 & $1881-1997$ & Oerter et al. (2000) \\
\hline $\mathrm{H} 72$ & -69.2 & 41.08 & 1214 & 1832-1999 & Nishio et al. (2002) \\
\hline Derwael Ice Rise IC12 & -70.25 & 26.34 & 450 & $1744-2011$ & Philippe et al. (2016) \\
\hline
\end{tabular}

building upon previous SMB compilation studies by Favier et al. (2013) and Frezzotti et al. (2013). Of the 79 records selected, 41 records extend over the past 200 years, and therefore this period has been selected as a focus for our reconstruction. All spatial correlations, plots, and trends presented during this period (with the exception of the Weddell Sea coast, WS) are based on multiple records in each region to avoid introduced errors associated with the switch to single sites. Prior to 1800 the number of records drops dramatically, with only eight records covering the past 500 years, four records covering the past 1000 years, and only the Law Dome, RICE, and WAIS ice cores covering the full 2000- year period. Therefore it was decided to limit our analysis to the past 1000 years.

\subsection{Modelled surface mass balance}

In this study we utilize the precipitation fields from the European Centre for Medium-Range Weather Forecasts (ECMWF) Interim Reanalysis (ERA; 1979 onwards; Simmons et al., 2007; Dee et al., 2011). It replaces the previous ERA-40 reanalysis with improved model physics and observational data supplemented by ECMWF operational archives, providing a better representation of the hydrological cycle in the high Southern Hemisphere latitudes than ear- 
lier reanalyses (Bromwich et al., 2011; Bracegirdle and Marshall, 2012). A recent evaluation of 3265 multiyear averaged in situ observations concluded that ERA-Interim exhibits the highest performance in capturing interannual variability in observed Antarctic precipitation of the available reanalysis products (Wang et al., 2016).

In addition, we use the latest version of RACMO version 2.3p2 (RACMO2.3p2), which succeeds RACMO2.3 (Van Wessem et al., 2014) and combines the hydrostatic dynamics of the High Resolution Limited Area Model (HIRLAM) with the physics package of the ECMWF Integrated Forecast System. RACMO2.3p2 has been specifically adapted for use over glaciated regions, as it is coupled to a multilayer snow model (Ettema et al., 2010) that calculates processes in the firn, such as grain size growth, firn compaction, meltwater percolation or retention, and meltwater runoff. As it also includes a drifting snow routine that calculates sublimation and divergence or convergence of blowing snow (Lenaerts et al., 2012), RACMO2.3p2 explicitly calculates all SMB components over the AIS.

ERA-Interim reanalysis data (Dee et al., 2011) force the model at its lateral boundaries and prescribe sea surface temperature and sea ice cover for the period 1979-2015. The relaxation zone, where the forcing is applied to RACMO2.3p2, is located over the oceans so that the model is able to evolve freely over the continent. An important update in RACMO2.3p2 with respect to RACMO2.3 is the addition of upper-air relaxation at the two top model layers as described in Van de Berg and Medley (2016); this improves the interannual variability of the modelled SMB, which now better matches annually resolved ice core records.

\subsection{Defining the regions}

One of the goals of this paper is to investigate the regional differences in snow accumulation and reduce the bias introduced in previous continental reconstructions, in which regions of high data density overpower the signal in data-sparse low-elevation and coastal zones. Therefore, the Antarctic continent is divided into seven geographical regions (Fig. 1), each with distinct climates. The East Antarctic Plateau (EAP) corresponds to locations in East Antarctica above $2000 \mathrm{~m}$ of elevation, allowing for the separation of ice cores with a continental signal from those with a marine signature. The coastal regions of East Antarctica were separated into DML, defined as the areas between $15^{\circ} \mathrm{W}$ and $70^{\circ} \mathrm{E}$, Wilkes Land coast (WL; 70-150 E), and Victoria Land (VL; 150$170^{\circ} \mathrm{E}$ ). The Weddell Sea coast (WS) covers the RonneFilchner Ice Shelf and into Coats Land $\left(60-15^{\circ} \mathrm{W}\right)$. Note the difference from the common usage of the geographical names; DML and WL in our definition refer only to the coastal regions, whereas the higher-altitude regions belong to EAP. In this study the AP is treated separately from the West Antarctic Ice Sheet (WAIS), with a division at $88^{\circ} \mathrm{W}$.

\subsection{Methods for composite time series}

The ice cores were first separated into geographical regions (Fig. 1a) and normalized based on the mean and standard deviation during the reference period 1960-1990. Based on the defined boundaries, the largest density of data is the EAP (accounting for $45 \%$ of the records); nevertheless, the spatial distribution of the data is often poor. There are inadequate records in high-accumulation coastal and slope areas and in the vast polar plateau, where snow accumulation is lower than $70 \mathrm{~mm}$ w.e. $\mathrm{yr}^{-1}$ and seasonally deposited chemical or physical signals are frequently erased or changed by the action of the near-surface wind (Eisen et al., 2008). To avoid biases introduced because of high data density, which is especially relevant in areas such as EAP and WAIS, records from the same grid box (chosen with a size of $2^{\circ}$ latitude and $10^{\circ}$ longitude) were averaged together. The standardized records were then averaged together to form the standardized regional composites.

\section{Results and discussion}

\subsection{Representative of regional SMB?}

Due to small-scale variations in surface slope and roughness, the snow accumulation at an ice core site may vary somewhat from the local spatial mean. The comparison between the annual average snow accumulation at each site and the annual average SMB from RACMO2.3p2 since 1979 is shown in Fig. 1b. Individual sites where the correlation is significant at $p>0.05$ are highlighted in Fig. 1a. Before we investigate the temporal changes in the records we first establish how representative each composite is of regional SMB by testing annual average snow accumulation against annual average (January to December) SMB from RACMO2.3p2 (Fig. 2) and precipitation from ERA-Interim (Fig. 3; direct SMB is not available from the reanalysis product). Areas of high correlation (red) indicate that a large fraction of snow accumulation variability in the composite time series is explained by the modelled SMB or precipitation variability during the period 1979-2010. The cut-off of 2010 was chosen as very few records extend beyond this.

Comparison with both RACMO2.3p2 SMB and ERAInterim precipitation suggests that the composite snow accumulation records from AP, WAIS, WL, DML, and VL (Figs. 2 and 3) are indeed representative of regional accumulation. These records capture $\sim 25-40 \%$ of the variance in their respective regions and may be used to investigate changes in SMB beyond the instrumental period. It is important to note that this comparison covers a relatively short time period (1979-2010) and a period of known climate forcing. In the Pacific sector the calibration period coincides with a shift in the phase of the Interdecadal Pacific Oscillation (IPO), which is known to influence the atmospheric circulation transporting moisture to Law Dome (Vance et al., 

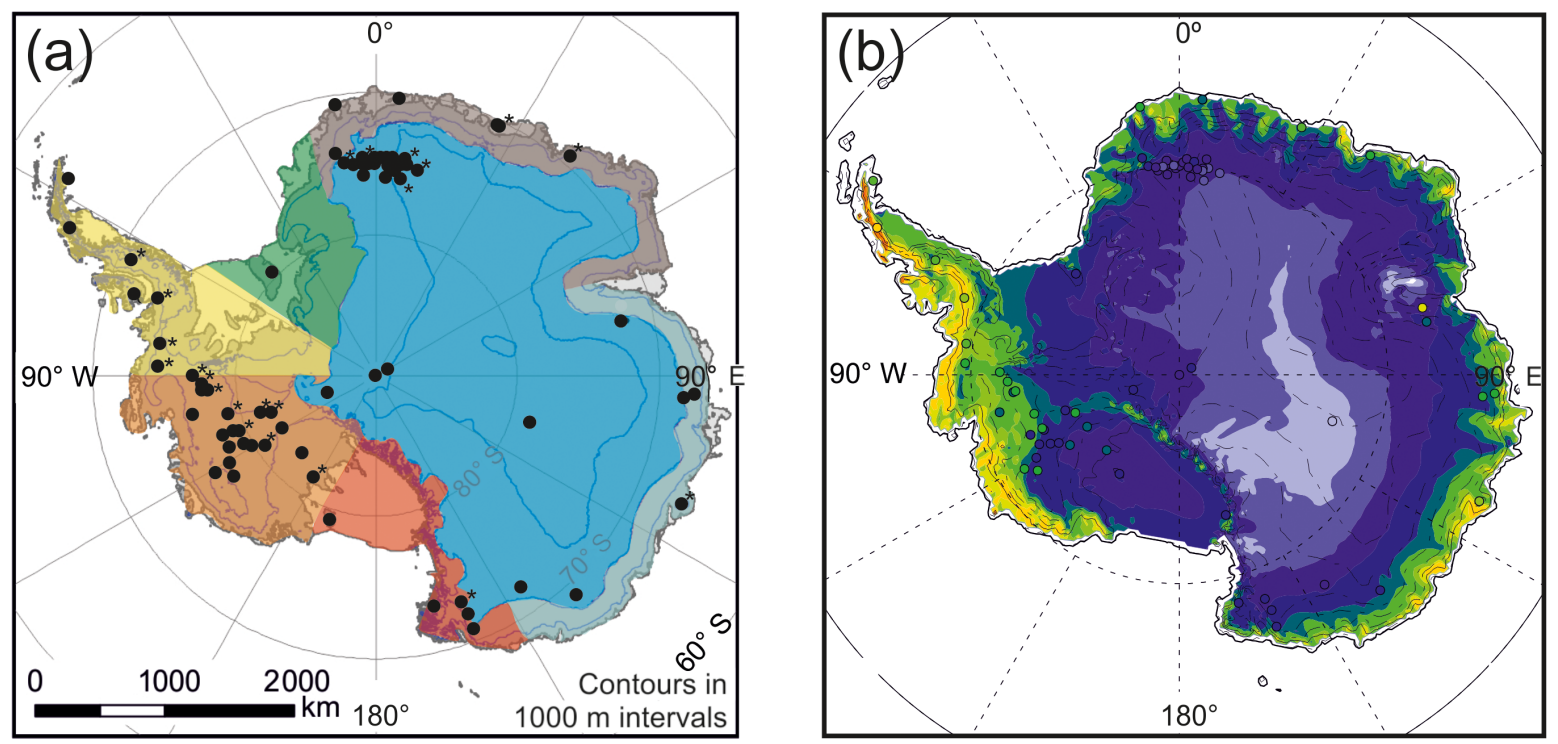

Figure 1. (a) Location of all ice cores and the regional boundaries used in this study. EAP (blue), WL (cyan), WS (green), AP (yellow), WAIS (orange), VL (red), and DML (brown). Stars denote sites where correlation between ice core snow accumulation and RACMO2.3p2 SMB is significant at $p<0.05$. (b) RACMO2.3p2 SMB (1979-2016) overlain with ice core SMB since 1979 at each location.

2015), from positive at the start of the period (1977-1997) to negative from the late 1990s. The Southern Annular Mode (SAM), the dominant mode of atmospheric variability in the Southern Hemisphere, is predominantly in its positive phase during this period, which has been demonstrated to influence precipitation, especially in AP (Thomas et al., 2008; Abram et al., 2014) and WAIS (Fogt et al., 2012; Raphael et al., 2016). Therefore, some care must be taken when extrapolating results beyond the instrumental period.

Despite the good agreement in most regions, the opposite is true for the records from EAP and WS. WS represents a single ice core and therefore we have been unable to reduce the signal-to-noise ratio achieved in the regions with multiple records spread over a large area. The poor relationship between snow accumulation and precipitation at this site may be a result of post-depositional changes at the coastal dome or reflect the model inability to capture precipitation and SMB variability at this site. In addition, there is a relatively small period of overlap with the modelled and reanalysis datasets (1979-1992).

The EAP has many records that cover the full calibration period (1979-2010), but they are restricted in the area of the DML plateau around Kohnen Station, the South Pole, and Talos Dome, while the inner part is represented only by the Vostok site. As such, the EAP composite is poorly related to SMB (Figs. 2a and 3a), but reducing the EAP area and producing smaller "subregions" is no improvement. One possible explanation is that the models do not take into account precipitation processes such as diamond dust that likely have a relatively large influence on precipitation variability in these extremely cold areas (van de Berg et al., 2005;
Mahesh et al., 2001). Additionally, large glaze and/or dune fields cover a large percentage (more than $500000 \mathrm{~km}^{2}$ ) of the EAP (Fahnestock et al., 2000) and these have been shown to significantly confound accumulation measurements in ice cores (Dixon et al., 2013). A combination of large topographical gradients and strong katabatic winds provides challenges for models in the grounding line area and this is where the largest differences appear between field data and the modelled SMB (e.g. Sinisalo et al., 2013). Large areas along the margins of the EAP are characterized by steep slopes and thus often suffer from challenges in describing the physical processes related to SMB in the lower-resolution model domains.

Modelled regional composites were produced by extracting annual RACMO2.3p2 SMB at each ice core site. The data were standardized and averaged following the same method as the ice core records (however, the reference period is 1979-2010 compared to 1969-1990 for the ice cores) and the resulting spatial correlations for each region are presented in Fig. S1 in the Supplement. The results demonstrate that even if the ice core records accurately captured SMB at each site (i.e. not subject to post-depositional changes), the resulting regional composite would still not represent regional changes because the spatial coverage is not good enough. For completeness we are including EAP and WS composites in this study; however, caution should be used when interpreting the climatological drivers and temporal changes in these regions.

The standardized regional composites have been averaged together to form a West Antarctic (WEST combines AP, WAIS, and VL), East Antarctic (EAST combines WS, DML, WL, and EAP), and continental (ALL combines all records) 

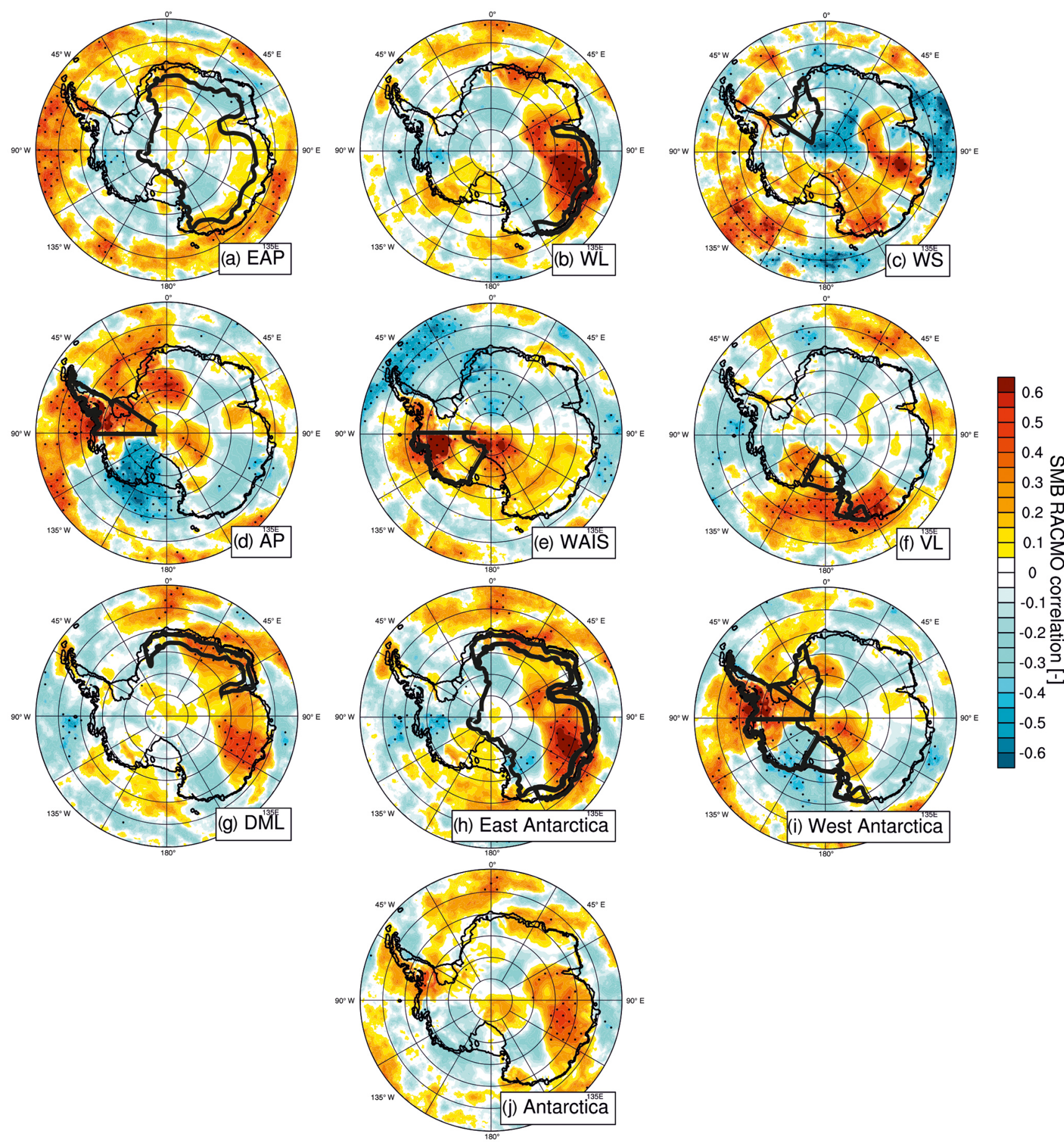

Figure 2. Spatial correlation plots of standardized regional and continental composites of snow accumulation with SMB from RACMO2.3p2 (1979-2010). Grid points with >95\% significance are dotted. Note that correlation with WS only covers the period 1979-1992.

composite by adopting a similar approach to previous SMB studies focusing on continental reconstructions (e.g. Monaghan et al., 2006a; Frezzotti et al., 2013). Evaluation with RACMO2.3p2 (Fig. 2) and ERA-Interim (Fig. 3) confirms that continental-style reconstructions reduce the representativeness of SMB and are susceptible to bias from highly sampled and high-accumulation areas. WEST resembles AP, EAST resembles WL, and ALL is a combination of these two regions, but with the area of significance across the whole continent significantly reduced. For this reason, our study will focus on regional SMB and not attempt to produce a continental reconstruction. 

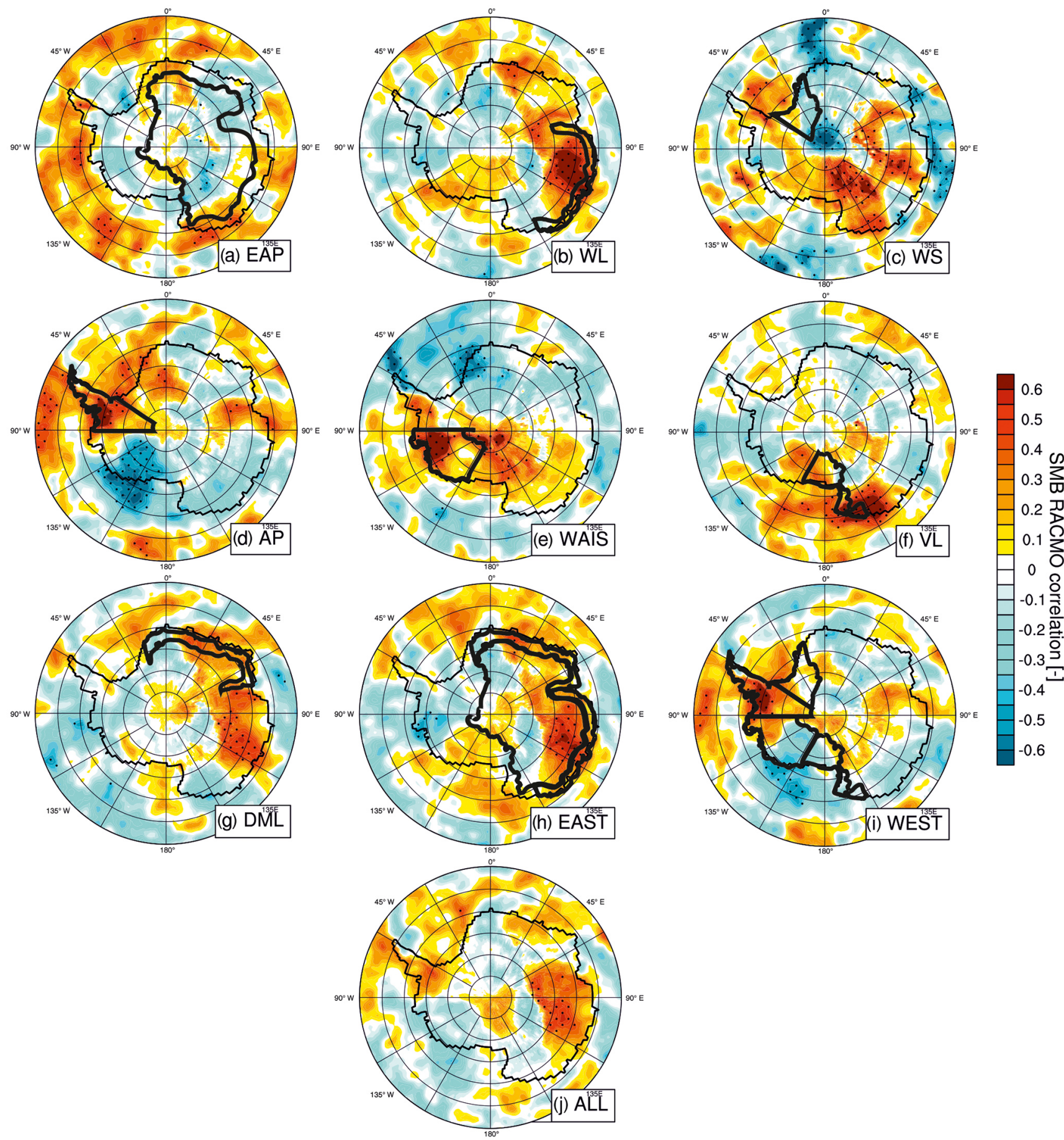

Figure 3. Spatial correlation plots of standardized regional and continental composites of snow accumulation with precipitation from ERAInterim (1979-2010). Grid points with > $95 \%$ significance are dotted. Note that correlation with WS only covers the period $1979-1992$.

Spatial correlation plots with SMB from RACMO2.3p2 (Fig. 2) and precipitation from ERA-Interim (Fig. 3) highlight some interesting relationships. Significant positive correlations with precipitation in AP are mirrored by negative correlations in WAIS, especially the region around Marie Byrd Land (Figs. 2d and 3d). The relationship is reversed for the WAIS composite, which reveals positive correlations with precipitation in continental WAIS but negative correlations in the northern AP (Figs. 2e and 3e). This pattern likely reflects the influence of the Amundsen Sea Low (ASL) and its association with the Antarctic Dipole and El NiñoSouthern Oscillation (ENSO; Yuan and Martinson, 2001). 
This persistent area of low pressure, the result of the frequency and intensity of individual cyclones (Baines and Fraedrich, 1989; Turner et al., 2013), is known to affect the climatic conditions on the AP and WAIS (Hosking et al., 2013; Thomas et al., 2015; Raphael et al., 2016).

In East Antarctica, positive correlations exist between WL and DML due to similar synoptic regimes and the influence of changes in the general atmospheric circulation, such as the Southern Annular Mode (SAM; e.g. Marshall, 2003) or zonal wave number 3 (ZW3) index (Raphael, 2007). We explore the drivers of regional SMB further by using the available meteorological data from ERA-Interim together with satellite observations of sea ice conditions.

\subsection{Drivers of regional precipitation}

\subsubsection{East Antarctic Plateau (EAP)}

Accumulation in EAP is generally extremely low $\left(<50 \mathrm{~mm} \mathrm{yr}^{-1}\right.$ on the high plateau) and exhibits high interannual variability. The temporally prevailing type of precipitation is diamond dust consisting of very fine needles or platelets formed when air in an almost saturated atmosphere is further cooled radiatively or mixed with the colder air of the inversion layer (Stenni et al., 2016; Walden et al., 2003). Much less frequently, synoptically caused snowfall occurs, which typically has daily amounts an order of magnitude higher than diamond dust precipitation. Thus a few snowfall events per year can yield up to $50 \%$ of the annual accumulation. The occurrence of such event-type precipitation is closely related to the amplification of Rossby waves, sometimes with corresponding blocking anticyclones (e.g. Massom et al., 2004), and is thus more frequent in the negative state of the SAM or positive ZW3 index (Raphael, 2007; Schlosser et al., 2016) when the meridional exchange of heat and moisture is increased. This agrees well with the pattern in Fig. 4a, which shows three distinct maxima in the correlation of SMB and the $850 \mathrm{hPa}$ geopotential height above the Southern Ocean between ca. 60 and $45^{\circ} \mathrm{S}$, south of South Africa and Australia and west of South America, respectively. A similar pattern is observed when comparing the SMB from RACMO2.3p2 with $850 \mathrm{hPa}$ geopotential height (Fig. S2), adding confidence that the ice core composite and the modelled SMB are influenced by similar atmospheric drivers. This spatial pattern is most likely due to the above-mentioned positive ZW3 index related to distinct troughs and ridges in the westerlies, which cause the advection of relatively warm and moist air to the interior of the continent (Noone et al., 1999; Schlosser et al., 2008, 2010a, b; Massom et al., 2004). There is no straightforward correlation with sea ice extent (Fig. 5a).
Ice and firn cores from EAP do not exhibit a uniform temporal trend. At Kohnen Station (EPICA DML drilling site), which is situated at $2892 \mathrm{~m}$ of elevation at the slope, an increase in SMB was found in the past 2 centuries (Oerter et al., 2000; Altnau et al., 2015). This is parallel to an increase in temperature (derived from stable isotopes) and thus most likely caused thermodynamically (Altnau et al., 2015). Anschütz et al. $(2009,2011)$ found no clear overall trend in SMB based on data from a traverse from coastal DML to the South Pole, with an increase at some sites and a decrease at others. However, above $3200 \mathrm{~m}$, all sites exhibited a decrease in SMB since 1963. Fujita et al. (2011) report that SMB data from a traverse between Dome Fuji and EPICA DML is strongly influenced by topography and is found to be approximately $15 \%$ higher in the second half of the 20th century than averages over centennial or millennial averages. No significant trend was found in accumulation rates in cores up to 100 years old before 1996 from Amundsenisen in DML (Oerter et al., 1999). The Dome C area (Frezzotti et al., 2005; Urbini et al., 2008) has exhibited high accumulation since the 1960s, as observed along the traverse between Dome Fuji and EPICA DML, whereas no significant changes have been apparent at Dome A since 1260 (Ding et al., 2011; Hou et al., 2009). In the Talos Dome area at the border between EAP and VL, century-scale variability shows a slight increase (of a few percent) in accumulation rates over the last 200 years, in particular since the 1960s, compared with the period 18161965 (Frezzotti et al., 2007).

\subsubsection{Wilkes Land coast (WL)}

The snow accumulation regime of Law Dome is determined by the intensity of the onshore transport of maritime air masses by cyclonic activity (Bromwich, 1988). While the magnitude of snow accumulation varies along the Wilkes Land coast, the accumulation is temporally coherent at least as far away as the Shackleton Ice Shelf (Roberts et al., 2015). In general, this region shows accumulation variability associated with both ENSO and IPO (Roberts et al., 2015; Vance et al., 2015), which influence the meridional component of the large-scale circulation (van Ommen and Morgan, 2010; Roberts et al., 2015; Vance et al., 2015).

Law Dome sea ice proxies (Curran et al., 2003; Vallelonga et al., 2017) are correlated with observations of sea ice extent. The weak negative correlation between WL accumulation and sea ice concentration (Fig. 5b) may be indicative of a common forcing from cyclonic systems depositing snow over Law Dome while also contributing to local sea ice break-up and/or dispersion.

\subsubsection{Weddell Sea coast (WS)}

The WS sector appears to exhibit a positive relationship with sea level pressure (SLP) in the South Pacific and over the Antarctic continent, while a negative relationship exists over 


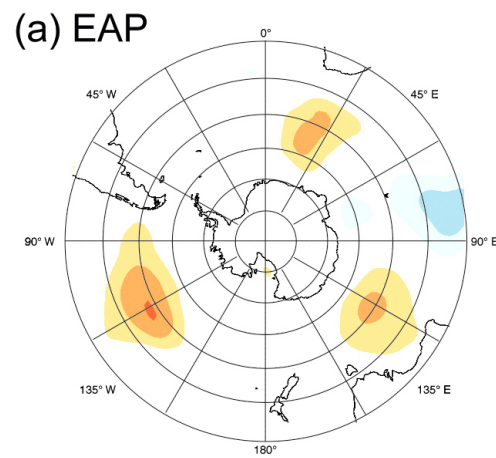

(d) AP

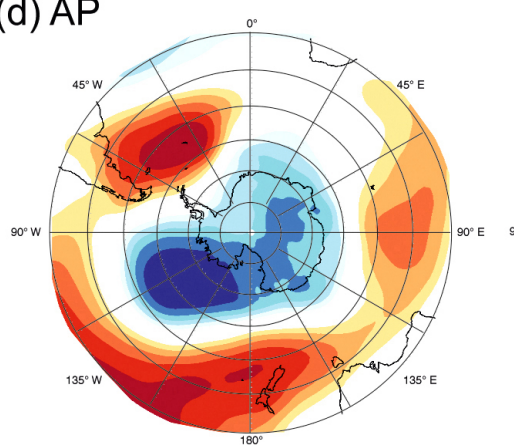

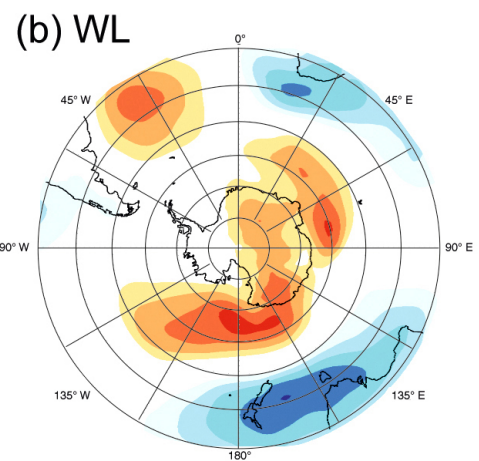

(e) WAIS

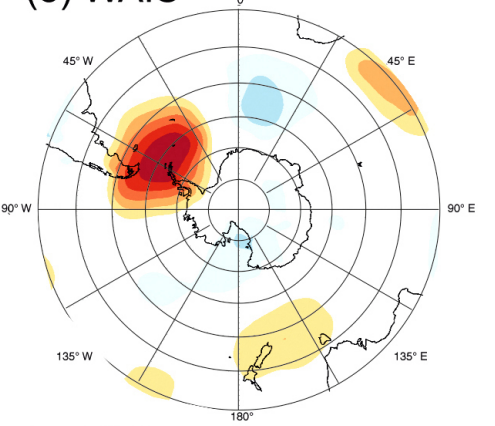

(g) DML

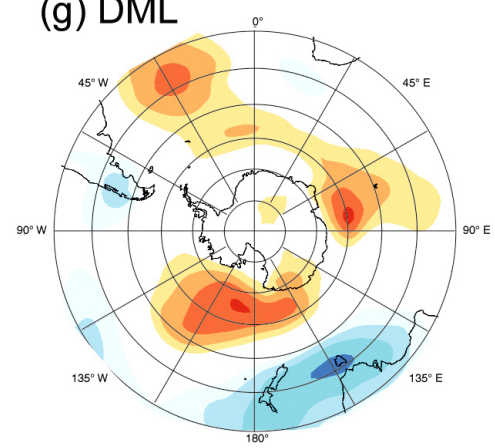

(c) WS

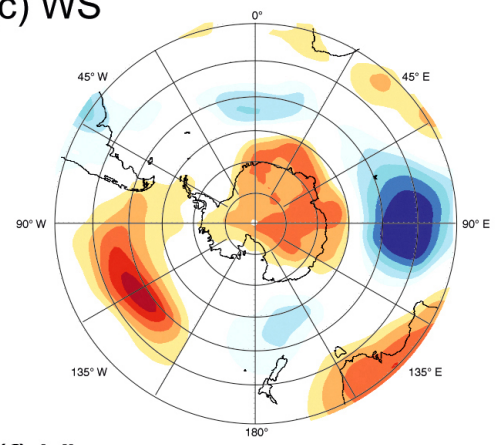

(f) VL

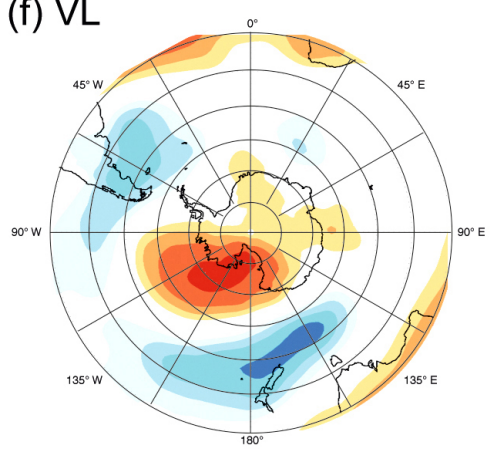

$\square-6 \frac{8}{0.5}$

$0.4 \cong$

0.3

0.2

0.1

0

-0.1 ญี

-0.2 而

$-0.3 \frac{1}{3}$

0.48

$0.5 \stackrel{1}{2}$

0.6

Figure 4. Spatial correlation plots of standardized regional snow accumulation composites with annual $850 \mathrm{hPa}$ geopotential heights from ERA-Interim (1979-2010). Grid points with >95\% significance are dotted. Note that correlation with WS only covers the period 1979-1992.

the southern Indian Ocean (Fig. 4c). However, this is based on just one ice core which is poorly related to modelled SMB and precipitation. Figure 5c suggests that snow accumulation is associated with sea ice concentration in the Weddell Sea, possibly resulting in enhanced moisture availability or reflecting an anticyclone that could draw more northerly air masses to the site. Unfortunately the reduced period of overlap for this site (1980-1992) makes the interpretation less reliable.

In order to establish the expected atmospheric drivers and relationship with sea ice, we repeat the spatial correlation plots in Figs. 4 and 5 using RACMO2.3p2 SMB. The relationship with $850 \mathrm{hPa}$ geopotential height is reversed when using the modelled SMB, with negative correlations over the Antarctic continent, especially over the Bellingshausen Sea (Fig. S2c), reminiscent of the pattern for AP (Figs. 4d and S1d). The strong correlations with sea ice concentration also disappear when using the modelled SMB, suggesting a positive correlation with sea ice in the Bellingshausen and northwestern Weddell Sea (Fig. S3c).

\subsubsection{Antarctic Peninsula (AP)}

SMB on the AP exhibits a large west-to-east gradient exceeding $3000 \mathrm{~mm}$ w.e. $\mathrm{yr}^{-1}$ on the western coast and less than $500 \mathrm{~mm}$ w.e. $\mathrm{yr}^{-1}$ on the eastern coast (Van Wessem et al., 2016), largely controlled by orography. The AP has been under-represented in previous SMB studies. However, recent drilling efforts have greatly increased the spatial coverage, but the high annual snowfall still limits the temporal coverage in this region. SMB in AP is dominated by the pattern of SLP in the Amundsen Sea (Fig. 4d), a region of high synoptic activity and the largest contributor to the total Antarctic meridional moisture flux (Tsukernik and Lynch, 2013), with the 


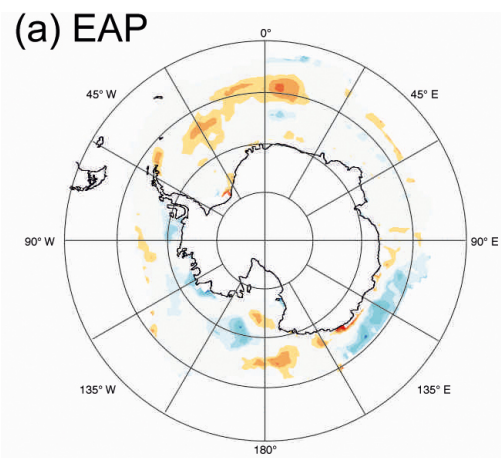

(d) AP

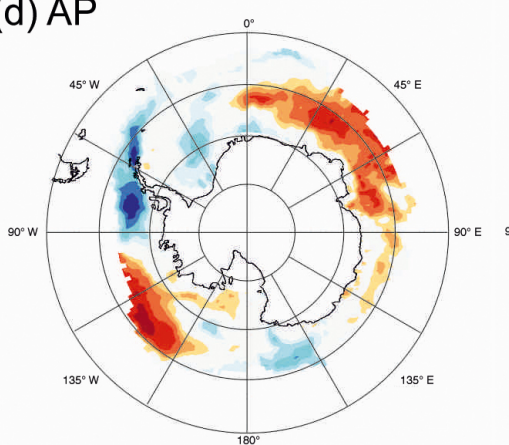

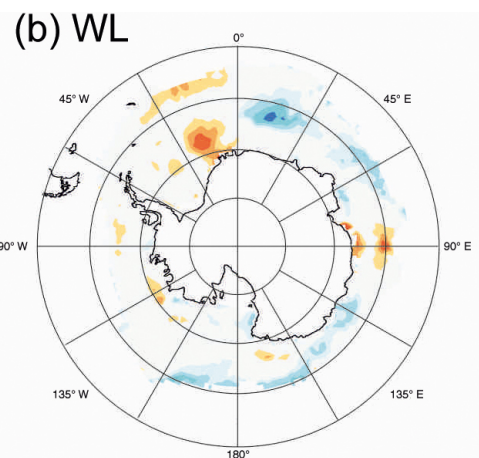

(e) WAIS

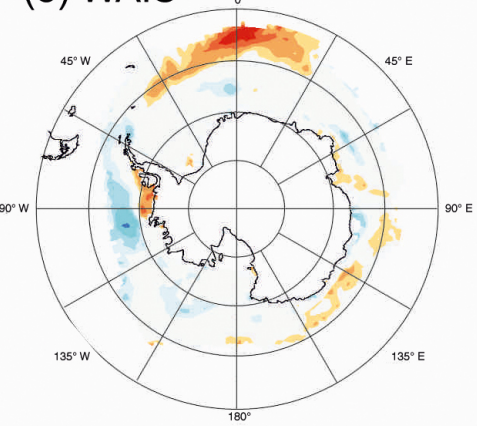

(g) DML

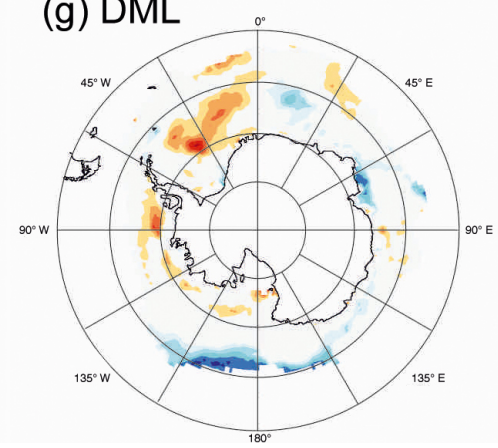

(c) WS

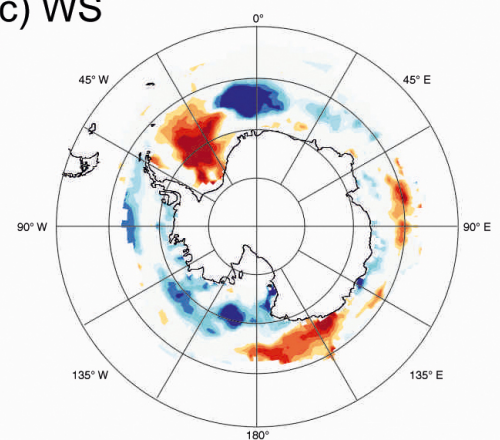

(f) VL

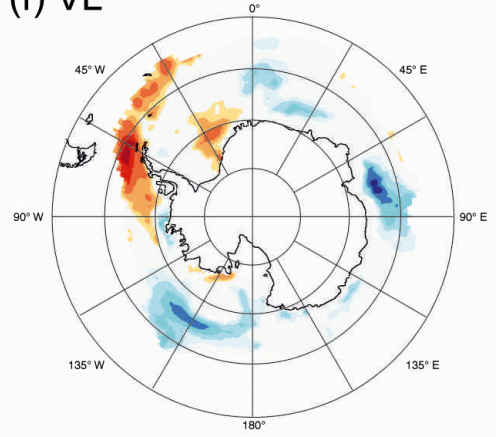

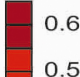

0.5

$-0.4 \stackrel{\mathbb{1}}{\mathbb{2}}$

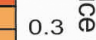

$-0.2 \stackrel{8}{\circ}$

Figure 5. Spatial correlation plots of standardized regional snow accumulation composites with annual sea ice concentration from bootstrap analysis (1981-2010). Grid points with > $95 \%$ significance are dotted. Note that correlation with WS only covers the period 1979-1992.

highest interannual and seasonal variability. High snow accumulation is associated with reduced regional SLP, leading to strengthened circumpolar westerlies and enhanced northerly flow. The mechanism of lower SLP in the Amundsen Sea sector creates a dipole pattern of enhanced precipitation in Ellsworth Land and reduced precipitation over western West Antarctica (Thomas et al., 2015), reflecting the clockwise rotation of air masses and moisture advection paths and explaining the dipole of correlations observed in Figs. 2 and 3.

AP ice cores reveal a significant increase in snowfall during the 20th century (Thomas et al., 2008, 2015; Goodwin et al., 2016), which has been linked to the positive phase of the SAM, marked by high pressure anomalies in the midlatitudes and stronger circumpolar westerly winds since the 1970s. ENSO also plays a role through the modulation of the South Pacific Convergence Zone (IPCZ); however, the relationship between snow accumulation and both SAM and ENSO is not temporally stable (Thomas et al., 2008, 2015; Goodwin et al., 2016). It has been suggested that the coupling between these two modes of variability modulates snow accumulation in the AP (Clem and Fogt, 2013) and may explain the acceleration since the 1990s when both modes are inphase. The increased snowfall has also been linked to warming sea surface temperatures in the western Pacific (Thomas et al., 2015), an area not associated with ENSO, and with the phase changes of the Pacific Decadal Oscillation (PDO), which exhibits major phase shifts in the late 1940s and mid1970s (Goodwin et al., 2016).

Snow accumulation in the Antarctic Peninsula is also closely related to sea ice conditions in the Bellingshausen Sea (Fig. 5d; Thomas et al., 2015; Porter et al., 2016). Sea ice plays an important role in the climate system by acting as a barrier for the transport of moisture and heat between the 
ocean and the atmosphere. Sea ice reconstructions have revealed a 20th century decline in sea ice in the Bellingshausen Sea (Abram et al., 2010) and evidence that the current rate of sea ice loss is unique for the post-1900 period (Porter et al., 2016). The result is enhanced availability of surface level moisture and increased poleward atmospheric moisture transport (Tsukernik and Lynch, 2013). This was used to explain the longitudinal differences between AP ice core sites (Thomas et al., 2015), with the least significant changes in accumulation in Ellsworth Land and the greatest changes observed in the south-western AP where adjacent sea ice exhibits the largest decreasing trend (Turner et al., 2009).

\subsubsection{West Antarctic Ice Sheet (WAIS)}

The WAIS region has been comparatively well sampled (Fig. 1) with records covering a large portion of the area and spanning many centuries. Although accumulation rates are relatively high, firn cores recovered as part of the WAIS Divide ice core project have provided records covering the past 2000 years. Because of its complex topography and divide geometries, the WAIS region is commonly differentiated into two smaller regions: the Amundsen Sea sector, home to Pine Island and Thwaites Glacier, and the Ross Sea sector where the Siple Coast ice streams flow into the Ross Ice Shelf.

The low-elevation terrain of the Amundsen Sea sector penetrates far into the interior; thus, the region is subject to frequent warm, marine air intrusions that bring cloud cover, higher amounts of snowfall, and higher temperatures (Nicolas and Bromwich, 2011). In general, the accumulation gradient is dependent on elevation; however, terrain geometry plays an important role. The steep coastal region of Marie Byrd Land receives relatively high accumulation because of orographic lifting, while the region directly south in the precipitation shadow of the Executive Committee Range is precipitation starved. Thus, the highest accumulation rates are found on the low-elevation coastal domes and much of the interior of the Amundsen Sea sector where marine air intrusions bring moisture and heat (Nicolas and Bromwich, 2011).

Because of the ice sheet geometry, the accumulation records from the Amundsen Sea sector are poorly correlated with those from the Ross Sea sector. Correlation of the WAIS record with RACMO2.3p2 SMB and ERA-Interim precipitation shows a very strong resemblance to the Amundsen Sea sector and a very weak relationship with the Ross Sea sector (Figs. 2e and 3e). Even though there are records from the Ross Sea sector (Fig. 1), they are largely out of date, covering up to the middle to late 1990s. Records from the Amundsen Sea sector provide data up to 2010; thus, the most recent decade of the WAIS record is composed of records only from the Amundsen Sea sector, which has a stronger correlation with modelled SMB. This limitation must be considered when evaluating the drivers of WAIS accumulation.
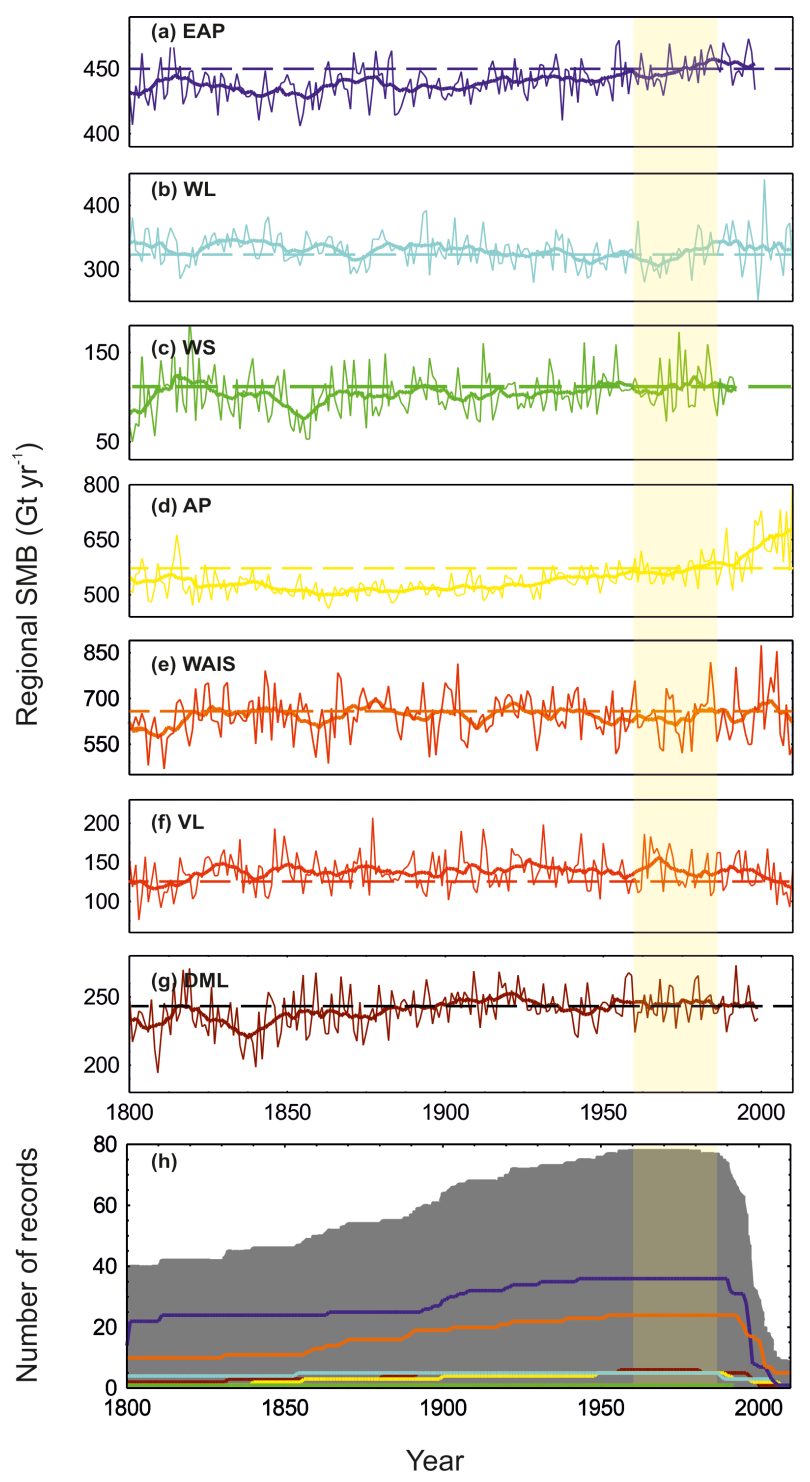

Figure 6. Regional SMB composites (1800-2010 AD) shown as annual averages (thin lines) and 5-year means (thick lines) for (ag) the East Antarctic Plateau (EAP, dark blue); Wilkes Land coast (WL, cyan), Weddell Sea coast (WS, green), Antarctic Peninsula (AP, yellow), West Antarctic Ice Sheet (WAIS, orange), Victoria Land (VL, red), and Dronning Maud Land (DML, brown). Panel (h) represents the total number of records (solid grey) and the number of records by region.

Higher atmospheric pressure over the Drake Passage brings enhanced northerly flow over the central Amundsen Sea and directs warm, moist air to the low-elevation central WAIS (Figs. 4e and 6e). The additional accumulation brought to the Amundsen Sea sector extends deep into the Antarctic interior, reaching the South Pole sector (Fig. 2e). This scenario is more representative of the Amundsen Sea than the Ross Sea sector, the latter being largely driven by the strength and position of the Amundsen Sea Low (Kas- 
pari et al., 2004; Nicolas and Bromwich, 2011; Thomas et al., 2015).

\subsubsection{Victoria Land (VL)}

For the purpose of this paper, we cluster records derived from the Ross Ice Shelf and the coastal regions (below $2000 \mathrm{~m}$ of elevation) of the Transantarctic Mountains (TAM) into VL (Fig. 1). Despite its geographical diversity ranging from a low-lying, flat ice shelf to the east (towards West Antarctica) to a steep relief in the west (towards East Antarctica), this region is dominated by cyclonically driven snow accumulation sensitive to tropical and local climate drivers that significantly impact the wider region (Bertler et al., 2017; Emanuelsson et al., 2017).

Accumulation in northern Victoria Land, where the coast faces north, comes primarily from storms in the Indian Ocean (Scarchilli et al., 2011), with the origin of air masses similar to that of adjacent Wilkes Land. However, the Transantarctic Mountains block flow to southern Victoria Land so that this region is influenced by storms that cross the Ross Sea (Sodeman and Stohl, 2009). As a consequence, the snow accumulation rates are higher in northern and southern Victoria Land, while the middle region (including the McMurdo Dry Valleys) lies in the precipitation shadows of cyclones from the north and the south, experiencing overall lower snow accumulation rates (Sinclair et al., 2010).

Accumulation across the Ross Ice Shelf and southern VL is linked to that of the AP and WAIS through the position and intensity of the ASL, which affects the frequency and trajectory of storms in the Ross Sea (Raphael et al., 2016; Turner et al., 2013; Fogt et al., 2012; Bertler et al., 2004). Markle et al. (2012) also found that the phase of ENSO, but not SAM, affected the frequency of Ross Sea storms reaching southern VL. In particular, blocking (ridging) events with a position and frequency determined by the intensity and position of the ASL (Renwick, 2005) have been identified as a major driver of snow precipitation in the eastern Ross Sea region, enhancing meridional flow across the eastern Ross Sea (Emanuelsson et al., 2017). The principal tropical teleconnection associated with the Rossby wave propagation from the western tropical Pacific exerts its influence on the entire Ross Sea region, with opposing influence between the east and west (Raphael et al., 2016; Bertler et al., 2017), which explains some of the differences observed in these two regions.

The availability of local moisture from open water in the Ross Sea is also associated with high-accumulation events (Sinclair et al., 2013). Furthermore, riming (deposition) might contribute as much as $28 \%$ of all precipitation events, in particular during winter at sites in the vicinity of polynyas, such as RICE (Tuohy et al., 2015). As rime is poorly captured in reanalysis data, the potentially significant contribution of rime at particular sites might be an important consideration in understanding regional precipitation differences.

The VL composite has the greatest correlation with precipitation in the northward-facing section of VL and the western portion of the Ross Sea (Fig. 3f). The correlation in the TAM is low, likely due to topographic complexity. The VL composite is positively correlated with geopotential heights in the eastern Ross Sea (Fig. 4f), illustrating the connection to the ASL, which is more pronounced for Roosevelt Island than for Talos Dome and Hercules Névé. The pattern resembles that of AP, although weaker and opposite in sign. When the ASL is shifted to the west, weaker storms more frequently penetrate into VL rather than being focused in central WAIS and AP.

\subsubsection{Dronning Maud Land (DML)}

Precipitation in coastal DML is closely connected to synoptic activity in the circumpolar trough and related frontal systems. Interannual variability in both temperature and precipitation is influenced by SAM, which partly determines the amount of the meridional exchange of heat and moisture. Generally, precipitation decreases from the coast towards the interior and local maxima can occur at the windward side of topographic features, such as ice rises on ice shelves or steep slopes of the escarpment (Rotschky et al., 2007; Schlosser et al., 2008; Vega et al., 2016). Katabatic winds also influence $\mathrm{SMB}$, especially at the grounding line, at the transition of ice shelf and grounded ice, leading to negative SMB values due to wind erosion and increased evaporation (Sinisalo et al., 2013; Schlosser et al., 2014).

The correlation plot of SMB and $850 \mathrm{hPa}$ geopotential height (Fig. 4g) exhibits three distinct maxima above the Southern Ocean; however, compared to EAP they are situated closer to the coast and shifted in longitude by approximately $30^{\circ}$. This also hints at a ZW3 pattern. There is also a fairly strong positive correlation with sea ice extent in the north-western Weddell Sea and a rather weak negative correlation with the area between 0 and $30^{\circ} \mathrm{E}$ (Fig. 5g). A plausible explanation for this could be that positive sea ice anomalies in the northern part of the Weddell Sea are often related to a comparably strong south-westerly flow that, taking into account Ekman transport, pushes the ice away from the coast; at the same time, new ice is formed close to the coast due to cold air advection and reopened polynyas (e.g. Schlosser et al., 2011). The compensating north-westerly flow further east could enhance precipitation in DML.

Ice and firn cores from coastal DML do not show a uniform trend over the past century. However, in recent decades, all but the core from Derwael Ice Rise (Philippe et al., 2016) agree in having a negative trend in SMB, whereas temperatures and stable isotope ratios are increasing or constant (Isaksson and Melvold, 2002; Schlosser et al., 2012; Sinisalo et al., 2013; Schlosser et al., 2014; Altnau et al., 2015; Vega et al., 2016). For some cores this negative trend is found for 
the last 100 years (e.g. Kaczmarska et al., 2004). This suggests that the SMB and precipitation in DML are influenced by atmospheric flow conditions, i.e. dynamically rather than thermodynamically as at EAP (Altnau et al., 2015).

\subsection{Regional precipitation variability over the past 200 years}

The standardized regional composites have been converted into records of SMB based on SMB extracted from RACMO2.3p2. We use a geometric mean regression technique, which allows for error in both the modelled SMB and the ice core snow accumulation (Smith, 2009), to convert the unitless standardized regional composites into regional SMB $\left(\mathrm{Gt} \mathrm{yr}^{-1}\right)$. This method allows for error in both the regional composites and the RACMO2.3p2 data and has been widely used for other ice core proxies, for example regressing sea ice proxies onto satellite-derived records of winter sea ice extent (Abram et al., 2010; Thomas and Abram, 2016).

The regional SMB records reveal significant variability since $1800 \mathrm{AD}$ (Fig. 6). With the exception of WL (Fig. 6b), all regions exhibit an increasing trend in SMB, with statistically significant trends in the EAP, WS, and DML $(+0.83$, +0.83 and $+0.96 \mathrm{Gt} \mathrm{decade}^{-1}$ ). The largest increase is observed in the AP where SMB has increased at a rate of $4.3 \mathrm{Gt}_{\text {decade }}{ }^{-1}$, representing a total increase in SMB of $123 \pm 44 \mathrm{Gt} \mathrm{yr}^{-1}$ between the average in the first decade (1801-1810) and the average in the last decade (2001-2010).

The 20th century increase observed in AP (Fig. 6d) is unusual in the context of the past 200 years. In this region, the annual average SMB during the most recent period is $88 \pm 49 \mathrm{Gt} \mathrm{yr}^{-1}$ higher than the reference period (19611990 ) and the running decadal mean during the early $2000 \mathrm{~s}$ exceeds 2 standard deviations above the record average for the entire 300-year period. SMB in the AP has been increasing at a rate of $12 \mathrm{Gt} \mathrm{decade}^{-1}$ since $1900(p<0.01)$, equivalent to a $138 \pm 58 \mathrm{Gt} \mathrm{yr}^{-1}(\sim 20 \%)$ increase between the decadal average at the start of the 20th century (1901-1910) and the decadal average at the start of the 21 st century (20012010). As observed in previous studies the increase in SMB in the AP began in $\sim 1930$ and accelerated during the 1990s (Thomas et al., 2008, 2015; Goodwin et al., 2016).

Histograms of running 50-year and 100-year trends are shown in Fig. 8. For AP, the positive trends observed in the most recent 50-year and 100-year period (1960-2010 and 1910-2010) are the highest since $1800 \mathrm{AD}$ and both significant at $p<0.01$. Conversely in VL, the negative trends observed during the same period are the lowest since $1800 \mathrm{AD}$, significant for the 50-year trend $(p<0.01)$ but not the 100 year trend. The rate of increase in snowfall in AP and the opposing decrease in VL during the late 20th and early 21 st century are exceptional in the context of the past 200 years and reflect the influence of the ASL, especially since the 1990s when SAM and ENSO are in-phase and the tropical teleconnection was strongest.
In DML, two of the three records which cover the entire 20th century reveal a decreasing trend. However, the Derwael Ice Rise record reveals a statistically significant increase in snow accumulation during the 20th century, resulting in the most recent 50-year trend in DML $(p<0.05)$ sitting outside of the expected range for the previous 200 years (Fig. 8g). Snow accumulation at this low-elevation coastal site has been related to sea ice and atmospheric circulation patterns (Philippe et al., 2016), with SMB during the most recent decade (2000-2010) $5 \%$ higher than the reference period.

The most recent 50-year and 100-year trends for the other regions (EAP, WS, and WAIS) fall within the range of expected variability. In WL, the most recent 100 -year trend is outside of the expected range, but it is not significant at $p<0.10$.

\subsection{Regional precipitation variability over the past 1000 years}

To assess the significance of the recent trends we extend the records back 1000 years (Fig. 7). Only the Law Dome, RICE, WAIS, and Berkner ice cores cover the full period and the increased variability in these regions beyond $\sim 1400 \mathrm{AD}$ is an artefact of the shift from multiple to single sites.

There is considerable interannual and multi-decadal variability in all records; however, there is little consistency or commonality between regions. Previous studies have related Antarctic SMB changes to solar irradiance (Frezzotti et al., 2013), with three periods of low accumulation variability identified at 1250-1300, 1420-1550, and 1660-1790 AD that correspond to periods of low solar activity. A decrease in snow accumulation for the entire Little Ice Age (defined as $\sim 1300-1800 \mathrm{AD}$ ) was also observed in the western Ross Sea by a lower-resolution record (Bertler et al., 2011). Examination of our regional composites over the past 1000 years indicates that this may be restricted to the EAP and perhaps small regions not captured in this array, with little evidence for a large-scale reduction in variability related to solar variability in other regions. The relatively low accumulation over EAP, combined with the major ( $>50 \%$ ) contribution of non-synoptic precipitation, may explain the stronger influence of solar variability over EAP, while local wind regimes in the TAM have been shown to be sensitive to solar radiation (Bertler et al., 2005). However, the updated network presented here suggests that the strong synoptic influence on coastal regions is likely to outweigh any direct solar influence.

\section{Total Antarctic SMB change}

An estimate of the SMB change for the total AIS (including ice shelves) is calculated by combining the areaintegrated regional composites. The direct SMB data from 

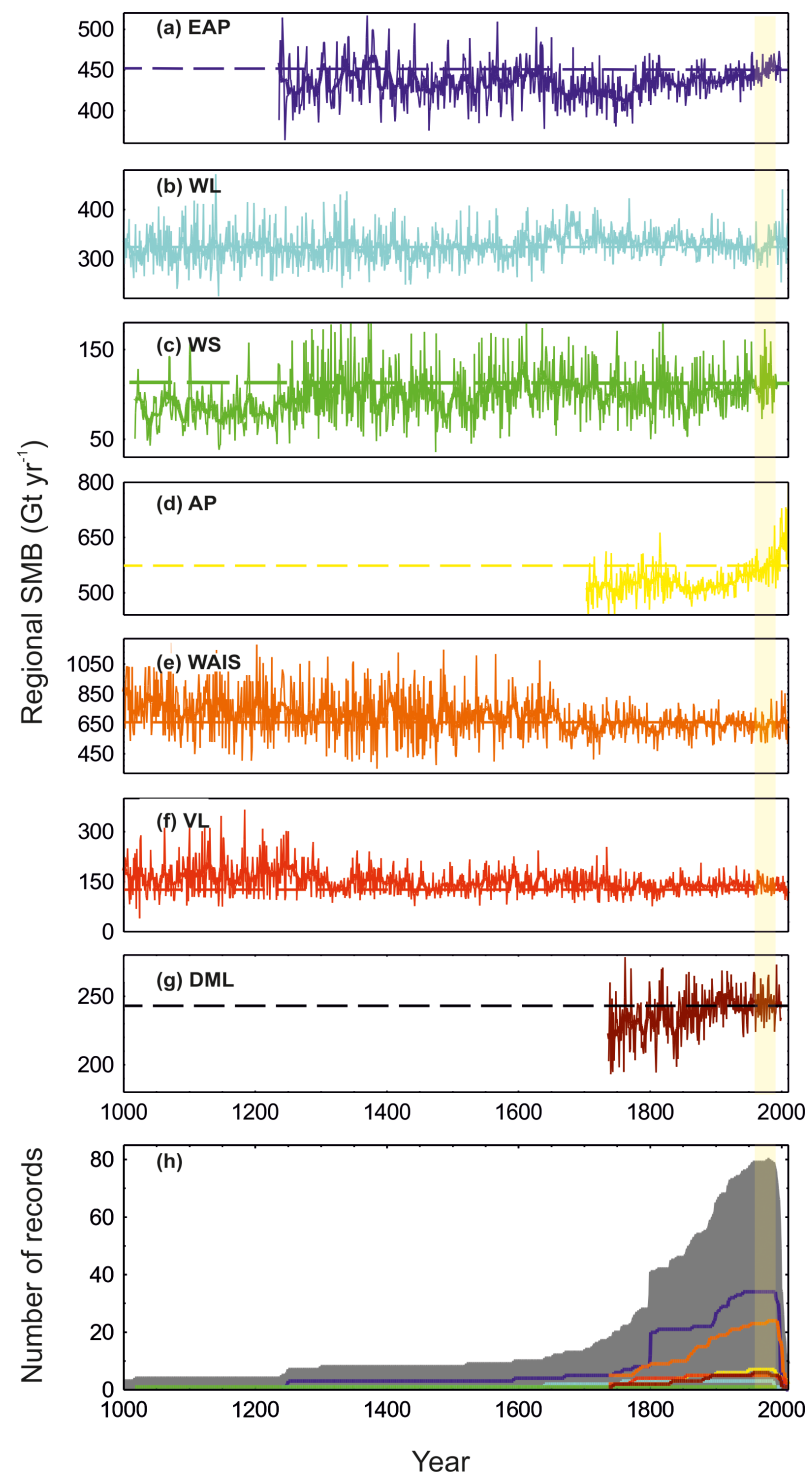

Figure 7. Regional SMB composites (1000-2010 AD) shown as annual averages (thin lines) and 10-year running means (thick lines) for (a-g) the East Antarctic Plateau (EAP, dark blue); Wilkes Land coast (WL, cyan), Weddell Sea coast (WS, green), Antarctic Peninsula (AP, yellow), West Antarctic Ice Sheet (WAIS, orange), Victoria Land (VL, red), and Dronning Maud Land (DML, brown). Panel (h) represents the total number of records (solid grey) and the number of records by region.

RACMO2.3p2 have been used to extend the reconstructions in EAP and WS to 2010 in line with the other regions.

The total Antarctic SMB increased at a rate of $7 \pm 1.3 \mathrm{Gtdecade}^{-1}$ between 1800 and $2010 \mathrm{AD}$ and $14 \pm 1.8 \mathrm{Gtdecade}^{-1}$ since $1900 \mathrm{AD}$ (Fig. 9). The annual average SMB for the AIS was $272 \pm 29 \mathrm{Gt} \mathrm{yr}^{-1}$ higher during the first decade of the 21 st century compared to the first decade of the 19th century. This equates to a relative reduction in sea level of $0.02 \mathrm{~mm} \mathrm{decade}^{-1}$ since $1800 \mathrm{AD}$ and
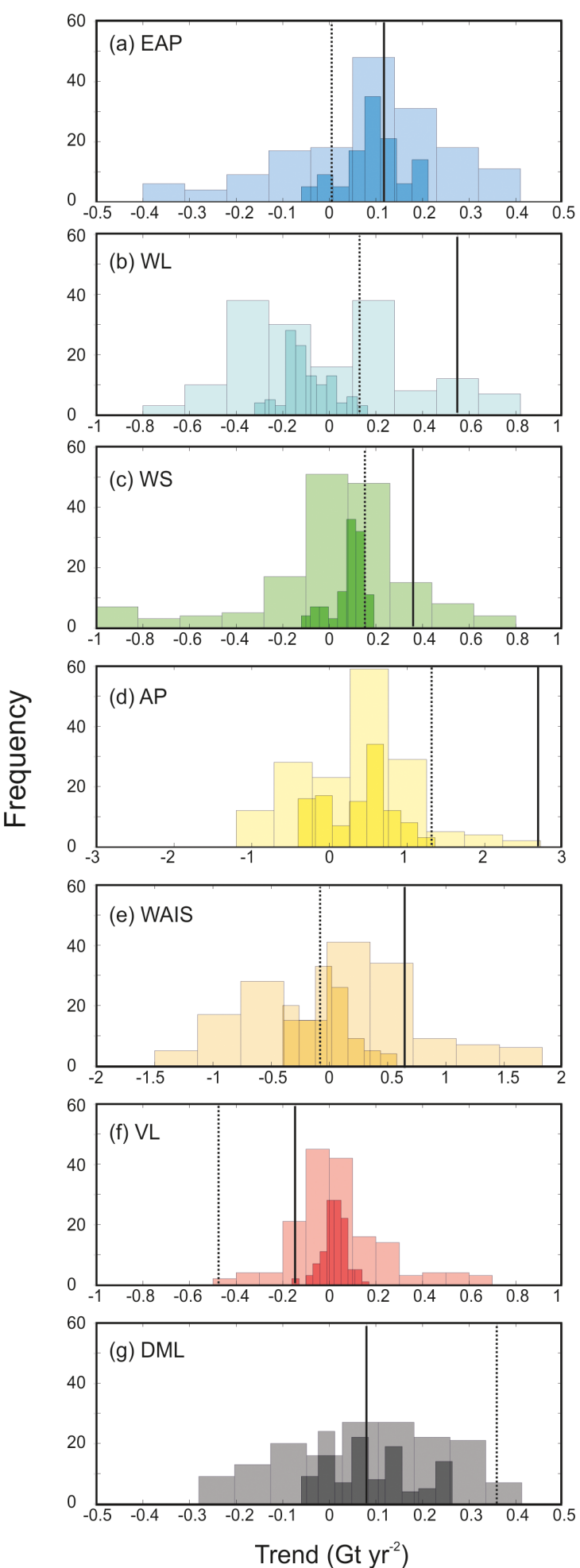

Figure 8. Histogram of running 50-year (lighter shading) and 100year (darker shading) trends for each region ( $\mathrm{mm}$ w.e. $\mathrm{yr}^{-1}$ ). The solid vertical line represents the most recent 50-year trend and the dashed vertical line the most recent 100-year trend (2010-1961 and 2010-1911, respectively). 

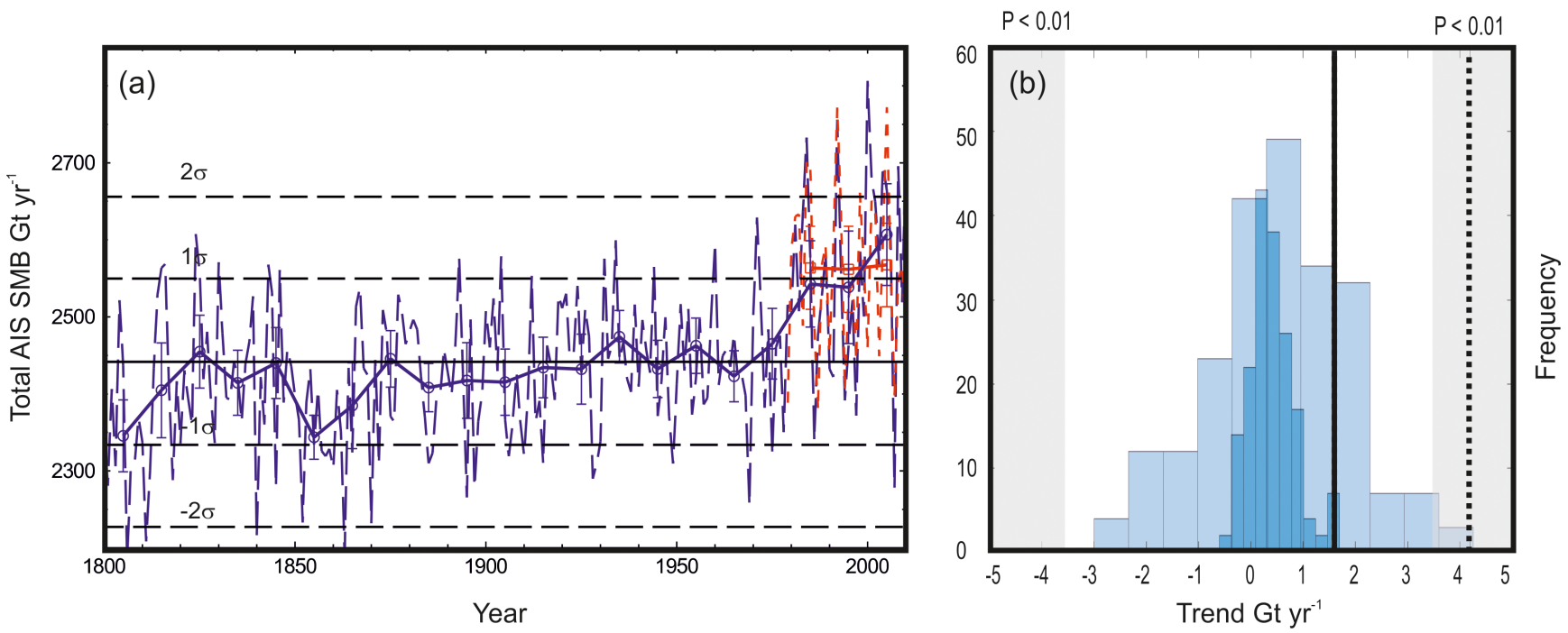

Figure 9. (a) Total AIS SMB derived from 80 ice core records (blue) and RACMO2.3p2 (red) as annual averages (dashed lines) and 10-year averages (solid line). The solid horizontal line represents the record average and the dashed horizontal lines are 1 and 2 standard deviations above and below this. (b) Histogram of 50-year (light shading) and 100-year (darker shading) trends in AIS SMB. The solid vertical line represents the most recent 50-year trend and the dashed vertical line the most recent 100-year trend (2010-1961 and 2010-1911, respectively).

$0.04 \mathrm{~mm} \mathrm{decade}^{-1}$ since $1900 \mathrm{AD}$, with the increased SMB acting to mitigate sea level rise as predicted under future warming scenarios (Palerme et al., 2017). The estimated sea level reduction resulting from the increased snowfall since $1800 \mathrm{AD}$ is comparable with the estimated mass loss and subsequent sea level contribution from the southern Patagonian ice fields (Glasser et al., 2011).

The largest (area-weighted) increase in SMB is observed in the AP, accounting for $\sim 75 \%$ of the total Antarctic SMB increase since 1900. Despite the relatively low annual snowfall, the EAP is the second-highest contributor (10\%) due to its extremely large area.

Only four records cover the full 1000 years (Fig. 7). The combined SMB in these regions (WAIS, WL, WS, and VL) suggests a decline of $\sim 1.4 \mathrm{Gtdecade}^{-1}$ since $1000 \mathrm{AD}$. However, it is important to note that these four regions represent just $\sim 30 \%$ of the total area of Antarctica and in the case of WS, doubt exists as to how regionally representative the record is. Evidence from the 20th century suggests that even small changes in SMB, in either the low-accumulation EAP region or the high-accumulation AP region, can have significant impacts on the total Antarctic SMB budget.

\section{Conclusions}

As part of the Antarctica 2k community effort, we present regional snow accumulation composites to investigate snow accumulation variability over the past 1000 years. Eighty ice core snow accumulation records were quality checked and separated into seven geographical regions to reduce the bias towards over-represented regions and separate the highaccumulation coastal zones from the low-accumulation highelevation sites.

The snow accumulation records from each region were evaluated against SMB from RACMO2.3p2 and precipitation from ERA-Interim. With the exception of the EAP and WS region, the regional composites capture a large proportion of the regional SMB and precipitation variability. The lack of correlation in the EAP is likely due to the greater influence of wind (erosion or deposition), sublimation, and postdepositional processes (surface glazing and dune formation) in the interior than in coastal regions. Another explanation is that the models cannot capture processes such as the deposition of diamond dust that likely have a relatively large influence on precipitation variability in these extremely cold areas (van de Berg et al., 2005; Mahesh et al., 2001). Either way, the lack of coherency in trends from ice core records across the central Antarctic Plateau suggests that ice core snow accumulation records from this region are less well suited to studies investigating temporal changes in Antarctic SMB.

Our study reveals that SMB for the total AIS has increased at a rate of $7 \pm 1.3 \mathrm{Gtdecade}^{-1}$ since $1800 \mathrm{AD}$, which is equivalent to a net reduction in sea level of $0.02 \mathrm{~mm}_{\text {decade }}{ }^{-1}$. The largest contribution is from the AP where the annual average SMB during the most recent decade (2001-2010) is $123 \pm 44 \mathrm{Gt} \mathrm{yr}^{-1}$ higher than the annual average at the start of the 19th century. The AP is the only region where both the most recent 50-year and 100year trends are outside of the observed range for the past 300 years. This contradicts some previous studies which suggest a negligible change in Antarctic SMB since 1957 (Mon- 
aghan et al., 2006a) and that the current SMB is not exceptionally high compared to the past 800 years (Frezzotti et al., 2013). Later studies did acknowledge high SMB in coastal regions since the 1960s; however, these studies were hindered by a lack of recent records (especially from the coastal zones) and were heavily weighted by the EAP region. Recent drilling campaigns and the collation of records as part of the Antarctica 2k programme have allowed us to better represent several important regions and derive a more accurate representation of SMB changes over the past 200 years.

The inclusion of new snow accumulation records that cover the past 1000 years has provided valuable information about SMB changes in certain regions; however, estimating Antarctic SMB using these sites alone would be misleading. For example, based on the four available records which cover the past 1000 years there is evidence for a decreasing trend in SMB since 1000 AD. However, the combined regional representation of these records is less than $30 \%$ of the total Antarctic continent and includes single ice core sites with only limited regional representation in SMB. Our findings suggest that small changes in the high-accumulation AP, or the low-accumulation but geographically much larger EAP region, could change the sign and significance of the total Antarctic SMB trend dramatically.

Greater spatial representation (especially WS and EAP) and the inclusion of sufficiently deep ice cores from highaccumulation coastal zones (especially AP and DML) are vital to our understanding of the true nature of Antarctic SMB in the past and to providing an accurate benchmark for how SMB may change in the future.

Data availability. The original snow accumulation data and the composite records produced in this study are available from the UK Polar Data Centre (Thomas, 2017) or by contacting Elizabeth R. Thomas (lith@bas.ac.uk). The complete data citation from all data used in this study is presented in Table S1 and stored alongside the original data and the composite data at the UK Polar Data Centre. The ECMWF ERA-Interim data and the RACMO data used in the spatial correlations are available at http://apps.ecmwf.int/ datasets/ and https://www.projects.science.uu.nl/iceclimate/models/ antarctica.php.

\section{The Supplement related to this article is available online at https://doi.org/10.5194/cp-13-1491-2017-supplement.}

Competing interests. The authors declare that they have no conflict of interest.

Special issue statement. This article is part of the special issue "Climate of the past 2000 years: regional and trans-regional syntheses". It is not associated with a conference.
Acknowledgements. This is a contribution to the PAGES $2 \mathrm{k}$ Network (through the Antarctica 2k project). Past Global Changes (PAGES) is supported by the US National Science Foundation and the Swiss Academy of Sciences. The project was also supported by the British Antarctic Survey (Natural Environment Research Council). We would like to thank the Antarctic ice core community for making their snow accumulation data available for this study and thank the data managers and PAGES team for their support. We thank two anonymous reviewers and the data review team for their comments and suggestions.

Edited by: Christian Turney

Reviewed by: two anonymous referees

\section{References}

Abram, N. J., Thomas, E. R., McConnell, J. R., Mulvaney, R., Bracegirdle, T. J., Sime, L. C., and Aristarain, A. J.: Ice core evidence for a 20th century decline of sea ice in the Bellingshausen Sea, Antarctica, J. Geophys. Res., 115, D23101, https://doi.org/10.1029/2010JD014644, 2010.

Abram, N. J., Mulvaney, R., Vimeux, F., Phipps, S. J., Turner, J., and England, M. H.: Evolution of the Southern Annular Mode during the past millennium, Nat. Clim. Change, 4, 564-569, 2014.

Agosta, C., Favier, V., Genthon, C., Gallée, H., Krinner, G., Lenaerts, J. T. M., and van den Broeke, M. R.: A 40-year accumulation dataset for Adelie Land, Antarctica and its application for model validation, Clim. Dynam., 38, 75-86, https://doi.org/10.1007/s00382-011-1103-4, 2012.

Allison, I., Alley, R., Fricker, H., Thomas, R., and Warner, R.: Ice sheet mass balance and sea level, Antarct. Sci., 21, 413-426, https://doi.org/10.1017/S0954102009990137, 2009.

Altnau, S., Schlosser, E., Isaksson, E., and Divine, D.: Climatic signals from 76 shallow firn cores in Dronning Maud Land, East Antarctica, The Cryosphere, 9, 925-944, https://doi.org/10.5194/tc-9-925-2015, 2015.

Anschütz, H., Eisen, O., Oerter, H., Steinhage, D., and Scheinert, M.: Investigating Small-Scale Variations of the Recent Accumulation Rate in Coastal Dronning Maud Land, East Antarctica, Ann. Glaciol., 46, 1-9, 2006.

Anschütz, H., Mueller, K., Isaksson, E., McConnell, J. R., Fischer, H., Miller, H., Albert, M., and Winther, J.-G.: Revisiting sites of the South Pole Queen Maud Land Traverses in East Antarctica: Accumulation data from shallow firn cores, J. Geophys. Res., 114, D24106, https://doi.org/10.1029/2009JD012204, 2009.

Anschütz, H., Sinisalo, A., Isaksson, E., McConnell, J. R., Hamran, S.-E., Bisiaux, M. M., Pasteris, D., Neumann, T. A., and Winther, J.-G.: Variation of accumulation rates over the last eight centuries on the East Antarctic Plateau derived from volcanic signals in ice cores, J. Geophys. Res., 116, D20103, https://doi.org/10.1029/2011JD015753, 2011.

Aristarain, A. J., Delmas, R. J., and Stievenard, M.: Ice-core study of the link between sea-salt aerosol, sea-ice cover and climate in the Antarctic Peninsula area, Clim. Change, 67, 63-86, 2004.

Arthern, R. J., Winebrenner, D. P., and Vaughan, D. G.: Antarctic snow accumulation mapped using polarization of $4.3-\mathrm{cm}$ wavelength microwave emission, J. Geophys. Res., 111, D06107, https://doi.org/10.1029/2004JD005667, 2006. 
Baines, P. G. and Fraedrich, K.: Topographic effects on the mean tropospheric flow patterns around Antarctica, J. Atmos. Sci., 46, 3401-3415, 1989.

Banta, J. R., McConnell, J. R., Frey, M. M., Bales, R. C., and Taylor, K.: Spatial and temporal variability in snow accumulation at the West Antarctic Ice Sheet Divide over recent centuries, J. Geophys. Res., 113, D23102, https://doi.org/10.1029/2008JD010235, 2008.

Bertler, N. A. N., Barrett, P. J., Mayewski, P. A., Fogt, R. L., Kreutz, K. J., and Shulmeister, J.: El Niño suppresses Antarctic warming, Geophys. Res. Lett., 31, L15207, https://doi.org/10.1029/2004GL020749, 2004.

Bertler, N. A. N., Barrett, P. J., Mayewski, P. A., Sneed, S. B., Naish, T. R., and Morgenstern, U.: Solar forcing recorded by aerosol concentrations in coastal Antarctic glacier ice, McMurdo Dry Valleys, Ann. Glaciol., 41, 52-56, 2005.

Bertler, N. A. N., Mayewski, P. A., and Carter, L.: Cold Conditions during the Little Ice Age - Implications for abrupt climate mechanisms, Earth Planet. Sc. Lett., 308, 41-51, https://doi.org/10.1016/j.epsl.2011.05.021, 2011.

Bertler, N. A. N., Conway, H., Dahl-Jensen, D., et al.: The Ross Sea Dipole - Temperature, Snow Accumulation and Sea Ice Variability in the Ross Sea Region, Antarctica, over the Past 2700 Years, Clim. Past Discuss., https://doi.org/10.5194/cp-2017-95, in review, 2017.

Bracegirdle, T. J. and Marshall, G. J.: The Reliability of Antarctic Tropospheric Pressure and Temperature in the Latest Global Reanalyses, J. Climate, 25, 7138-7146, https://doi.org/10.1175/JCLI-D-11-00685.1, 2012.

Bromwich, D. H.: Snowfall in high southern latitudes, Rev. Geophys., 26, 149-168, https://doi.org/10.1029/RG026i001p00149, 1988.

Bromwich, D. H., Nicolas, J. P., and Monaghan, A. J.: An assessment of precipitation changes over Antarctica and the Southern Ocean since 1989 in contemporary global reanalyses, J. Climate, 24, 4189-4209, https://doi.org/10.1175/2011JCLI4074.1, 2011.

Chen, J. L., Wilson, C. R., Blankenship, D., and Tapley, B. D.: Accelerated Antarctic ice loss from satellite gravity measurements, Nat. Geosci., 2, 859-862, https://doi.org/10.1038/ngeo694, 2009.

Clem, K. R. and Fogt, R. L.: Varying roles of ENSO and SAM on the Antarctic Peninsula climate in austral spring, J. Geophys. Res.-Atmos, 118, 11481-11492, 2013.

Curran, M., Van Ommen, T., Morgan, V., Phillips, K., and Palmer, A.: Ice core evidence for Antarctic sea ice decline since the 1950s, Science, 302, 1203-1206, 2003.

Dansgaard, W. and Johnsen, S.: A flow model and time scale for the ice core from Camp Century, Greenland, J. Glaciol., 8, 215-223, 1969.

Dee, D. P., Uppala, S. M., Simmons, A. J., Berrisford, P., Poli, P., Kobayashi, S., Andrae, U., Balmaseda, M. A., Balsamo, G., Bauer, P., Bechtold, P., Beljaars, A. C. M., van de Berg, L., Bidlot, J., Bormann, N., Delsol, C., Dragani, R., Fuentes, M., Geer, A. J., Haimberger, L., Healy, S. B., Hersbach, H., Hólm, E. V., Isaksen, L., Kållberg, P., Köhler, M., Matricardi, M., McNally, A. P., Monge-Sanz, B. M., Morcrette, J.-J., Park, B.-K., Peubey, C., de Rosnay, P., Tavolato, C., Thépaut, J.-N. and Vitart, F.: The ERA-Interim reanalysis: Configuration and performance of the data assimilation system, Q. J. Roy. Meteor. Soc., 137, 553-597, https://doi.org/10.1002/qj.828, 2011.

Ding, M., Xiao, C., Li, Y., Ren, J., Hou, S., Jin, B., and Sun, B.: Spatial variability of surface mass balance along a traverse route from Zhongshan station to Dome A, Antarctica, J. Glaciol., 57, 658-666, https://doi.org/10.3189/002214311797409820, 2011.

Dixon, D. A., Mayewski, P. A., Korotkikh, E., Sneed, S. B., Handley, M. J., Introne, D. S., and Scambos, T. A.: Variations in snow and firn chemistry along US ITASE traverses and the effect of surface glazing, The Cryosphere, 7, 515-535, https://doi.org/10.5194/tc-7-515-2013, 2013.

Eisen, O., Frezzotti, M., Genthon, C., Isaksson, E., Magand, O., van den Broeke, M. R., Dixon, D. A., Ekaykin, A., Holmlund, P., Kameda, T., Karlöf, L., Kaspari, S., Lipenkov, V. Y., Oerter, H., Takahashi, S., and Vaughan, D. G.: Ground-based measurements of spatial and temporal variability of snow accumulation in East Antarctica, Rev. Geophys., 46, RG2001, https://doi.org/10.1029/2006RG000218, 2008.

Ekaykin, A. A., Kozachek, A. V., Lipenkov, V. Y., and Shibaev, Y. A.: Multiple climate shifts in the Southern Hemisphere over the past three centuries based on central Antarctic snow pits and core studies, Ann. Glaciol., 55, 259-266, https://doi.org/10.3189/201AoG66A189, 2014.

Ekaykin, A. A., Vladimirova, D. O., Lipenkov, V. Y., and MassonDelmotte, V.: Climatic variability in Princess Elizabeth Land (East Antarctica) over the last 350 years, Clim. Past, 13, 61-71, https://doi.org/10.5194/cp-13-61-2017, 2017.

Emanuelsson, B. D., Bertler, N. A. N., Renwick, J. A., Markle, B. R., Baisden, W. T., Keller, E. D., and Neff, P., D.: The role of the Amundsen-Bellingshausen Sea anticyclonic circulation for marine air mass intrusions into West Antarctica, Clim. Dynam., submitted, 2017.

Ettema, J., van den Broeke, M. R., van Meijgaard, E., van de Berg, W. J., Box, J. E., and Steffen, K.: Climate of the Greenland ice sheet using a high-resolution climate model - Part 1: Evaluation, The Cryosphere, 4, 511-527, https://doi.org/10.5194/tc-4511-2010, 2010.

Fahnestock, M. A., Scambos, T. A., Shuman, C. A., Arthern, R. J., Winebrenner, D. P., and Kwok, R.: Snow megadune fields on the East Antarctic Plateau: extreme atmosphere-ice interaction, Geophys. Res. Lett., 27, 3719-3722, 2000.

Favier, V., Agosta, C., Parouty, S., Durand, G., Delaygue, G., Gallée, H., Drouet, A.-S., Trouvilliez, A., and Krinner, G.: An updated and quality controlled surface mass balance dataset for Antarctica, The Cryosphere, 7, 583-597, https://doi.org/10.5194/tc-7-583-2013, 2013.

Fogt, R. L., Wovrosh, A. J., Langen, R. A., and Simmonds, I.: The characteristic variability and connection to the underlying synoptic activity of the AmindsenBellinghausen Seas Low, J. Geophys. Res., 117, D07111, https://doi.org/10.1029/2011JD017337, 2012.

Frezzotti, M., Pourchet, M., Flora, O., Gandolfi, S., Gay, M., Urbini, S., Vincent, C., Becagli, S., Gragnani, R., Proposito, M., Severi, M., Traversi, R., Udisti, R., and Fily, M.: Spatial and temporal variability of snow accumulation in East Antarctica from traverse data, J. Glaciol., 51, 113-124, 2005.

Frezzotti, M., Urbini, S., Proposito, M., Scarchilli, C., and Gandolfi, S.: Spatial and temporal variability of surface mass bal- 
ance near Talos Dome, East Antarctica, J. Geophys. Res., 112, F02032, https://doi.org/10.1029/2006JF000638, 2007.

Frezzotti, M., Scarchilli, C., Becagli, S., Proposito, M., and Urbini, S.: A synthesis of the Antarctic surface mass balance during the last $800 \mathrm{yr}$, The Cryosphere, 7, 303-319, https://doi.org/10.5194/tc-7-303-2013, 2013.

Frieler, K., Clark, P. U., He, F., Buizert, C., Reese, R., Ligtenberg, S. R. M., van den Broeke, M. R., Winkelmann, R., and Levermann, A.: Consistent evidence of increasing Antarctic accumulation with warming, Nat. Clim. Change, 5, 348-352, https://doi.org/10.1038/nclimate2574, 2015.

Fudge, T. J., Markle, B. R., Cuffey, K. M., Buizert, C., Taylor, K. C., Steig, E. J., Waddington, E. D., Conway, H., and Koutnik, M.: Variable relationship between accumulation and temperature in West Antarctica for the past 31000 years, Geophys. Res. Lett., 43, 3795-3803, https://doi.org/10.1002/2016GL068356, 2016.

Fujita, S., Holmlund, P., Andersson, I., Brown, I., Enomoto, H., Fujii, Y., Fujita, K., Fukui, K., Furukawa, T., Hansson, M., Hara, K., Hoshina, Y., Igarashi, M., Iizuka, Y., Imura, S., Ingvander, S., Karlin, T., Motoyama, H., Nakazawa, F., Oerter, H., Sjöberg, L. E., Sugiyama, S., Surdyk, S., Ström, J., Uemura, R., and Wilhelms, F.: Spatial and temporal variability of snow accumulation rate on the East Antarctic ice divide between Dome Fuji and EPICA DML, The Cryosphere, 5, 1057-1081, https://doi.org/10.5194/tc-5-1057-2011, 2011.

Glasser, N. F., Harrison, S., Jansson, K. N., Anderson, K., and Cowley, A.: Global sea level contribution from the Patagonian Icefields since the Little Ice Age maximum, Nat. Geosci., 4, 303307, 2011.

Goodwin, B. P., Mosley-Thompson, E., Wilson, A. B., Porter, S. E., and Sierra-Hernandez, M. R.: Accumulation Variability in the Antarctic Peninsula: The Role of Large-Scale Atmospheric Oscillations and Their Interactions, J. Climate, 29, 2579-2596, 2016.

Hosking, J. S., Orr, A., Marshall, G. J., Turner, J., and Phillips, T.: The influence of the Amundsen-Bellingshausen Seas Low on the climate of West Antarctica and its representation in coupled climate model simulations, J. Climate, 26, 6633-6648, 2013.

Hou, S. G., Li, Y. S., Xiao, C. D., Pang, H. X., and Xu, J. Z.: Preliminary results of the close-off depth and the stable isotopic records along a $109.91 \mathrm{~m}$ ice core from Dome A, Antarctica, Sci. China Ser. D, 52, 1502-1509, https://doi.org/10.1007/s11430009-0039-6, 2009.

IPCC: Climate Change 2013: The Physical Science Basis, edited by: Stocker, T. F., Qin, D., Plattner, G.-K., Tignor, M., Allen, S. K., Boschung, J., Nauels, A., Xia, Y., Bex, V., and Midgley, P. M., Cambridge University Press, Cambridge, UK, 1535 pp., 2013.

Isaksson, E. and Melvold, K.: Trends and patterns in the recent accumulation and proxy-temperature in coastal Dronnning Maud Land, Antarctica - interpretations from shallow ice cores, Ann. Glaciol., 35, 175-180, 2002.

Isaksson, E., van den Broeke, M., Winther, J., Karlöf, L., Pinglot, J., and Gundestrup, N.: Accumulation and proxytemperature variability in Dronning Maud Land, Antarctica, determined from shallow firn cores, Ann. Glaciol., 29, 17-22, https://doi.org/10.3189/172756499781821445, 1999.

Kaczmarska, M., Isaksson, E., Karlöf, K., Winther, J.-G., Kohler, J., Godtliebsen, F., Ringstad Olsen, L., Hofstede, C. M., van den Broeke, M. R., Van De Wal, R. S. W., and Gundestrup, N.: Accu- mulation variability derived from an ice core from coastal Dronning Maud Land, Antarctica, Ann. Glaciol., 39, 339-345, 2004.

Kaspari, S., Mayewski, P. D., Dixon, D. A., Spikes, V. B., Sneed, S. B., Handley, M. J., and Hamilton, G. S.: Climate variability in West Antarctica derived from annual accumulation-rate records from ITASE firn/ice cores, Ann. Glaciol., 39, 585-594, https://doi.org/10.3189/172756404781814447, 2004.

Kobayashi, S., Ota, Y., Harada, Y., Ebita, A., Moriya, M., Onoda, H., and Takahashi, K.: The JRA-55 Reanalysis: General Specifications and Basic Characteristics, J. Meteorol. Soc. Jpn. Ser. II, 93, 5-48, https://doi.org/10.2151/jmsj.2015-001, 2015.

Krinner, G., Magand, O., Simmonds, I., Genthon, C., and Dufresne, J.-L.: Simulated Antarctic precipitation and surface mass balance at the end of twentieth and twenty-first centuries, Clim. Dynam., 28, 215-230, https://doi.org/10.1007/s00382-006-0177-x, 2007.

Lenaerts, J. T. M. and van den Broeke, M. R.: Modeling drifting snow in Antarctica with a regional climate model: 2. Results, J. Geophys. Res., 117, D05109, https://doi.org/10.1029/2010JD015419, 2012.

Lenaerts, J. T. M., van den Broeke, M. R., van de Berg, W. J., van Meijgaard, E., and Kuipers Munneke, P.: A new, high-resolution surface mass balance map of Antarctica (1979-2010) based on regional atmospheric climate modeling, Geophys. Res. Lett., 39, L04501, https://doi.org/10.1029/2011GL050713, 2012.

Lenaerts, J. T. M., van Meijgaard, E., van den Broeke, M. R., Ligtenberg, S. R. M., Horwath, M., and Isaksson, E.: Recent snowfall anomalies in Dronning Maud Land, East Antarctica, in a historical and future climate perspective, Geophys. Res. Lett., 40, 2684-2688, https://doi.org/10.1002/grl.50559, 2013.

Ligtenberg, S. R. M., van de Berg, W. J., van den Broeke, M. R., Rae, J. G. L., and van Meijgaard, E.: Future surface mass balance of the Antarctic ice sheet and its influence on sea level change, simulated by a regional atmospheric climate model, Clim. Dynam., 41, 867-884, https://doi.org/10.1007/s00382-013-1749-1, 2013.

Lliboutry, L.: A critical review of analytical approximate solutions for steady state velocities and temperatures in cold ice sheets, $\mathrm{Z}$. Gletsch.kd. Glazialgeol., 15, 135-148, 1979.

Mahesh, A., Walden, V. P., and Warren, S. G.: Ground-Based Infrared Remote Sensing of Cloud Properties over the Antarctic Plateau. Part II: Cloud Optical Depths and Particle Sizes, J. Appl. Meteorol., 40, 1279-1294, https://doi.org/10.1175/15200450(2001)040<1279:GBIRSO>2.0.CO;2, 2001.

Markle, B. R., Berler, N. A. N., Sinclair, K. E., and Sneed, S. B.: Synoptic variability in the Ross Sea region, Antarctica, as seen from back-trajectory modelling and ice core analysis, J. Geophys. Res.-Atmos., 117, D02113, https://doi.org/10.1029/2011JD016437, 2012.

Marshall, G.: Trend in the Southern Annular Mode from observations and reanalysis, J. Climate, 16, 4134-4143, 2003.

Massom, R. A., Pook, M. J., Comiso, J. C., Adams, N., Turner, J., Lachlan-Cope, T., and Gibson, T.: Precipitation over the interior East Antarctic ice sheet related to mid-latitude blocking-high activity, J. Climate, 17, 1914-1928, 2004.

Mayewski, P. A. and Dixon, D. A.: U.S. International Trans Antarctic Scientific Expedition (US ITASE) glaciochemical data, version 2. National Snow and Ice Data Center, accessed: 5 January 2015, https://doi.org/10.7265/N51V5BXR, 2013. 
Medley, B., Joughin, I., Das, S. B., Steig, E. J., Conway, H., Gogineni, S., Criscitiello, A. S., McConnell, J. R., Smith, B. E., van den Broeke, M. R., Lenaerts, J. T. M., Bromwich, D. H., and Nicolas, J. P.: Airborne-radar and ice-core observations of annual snow accumulation over Thwaites Glacier, West Antarctica confirm the spatiotemporal variability of global and regional atmospheric models, Geophys. Res. Lett., 40, 3649-3654, https://doi.org/10.1002/grl.50706, 2013.

Monaghan, A. J., Bromwich, D. H., Fogt, R. L., Wang, S.H., Mayewski, P. A., Dixon, D. A., Ekaykin, A., Frezzotti, M., Goodwin, I., Isaksson, E., Kaspari, S. D., Morgan, V. I., Oerter, H., Van Ommen, T. D., Van der Veen, C. J., and Wen, J.: Insignificant change in Antarctic snowfall since the international geophysical year, Science, 313, 827-831, https://doi.org/10.1126/science.1128243, 2006a.

Monaghan, A. J., Bromwich, D. H., and Wang, S.-H.: Recent trends in Antarctic snow accumulation from Polar MM5 simulations, Philos. T. R. Soc. Lon., 364, 1683-1708, https://doi.org/10.1098/rsta.2006.1795, 2006b.

Mosley-Thompson, E., Paskievitch, J. F., Gow, A. J., and Thompson, L. G.: Late 20th century increase in South Pole snow accumulation, J. Geophys. Res., 104, 3877-3886, 1999.

Mulvaney, R., Oerter, H., Peel, D. A., Graf, W., Arrowsmith, C., Pasteur, E. C., Knight, B., Littot, G. C., and Miners, W. D.: 1000 year ice-core records from Berkner Island, Antarctica, Ann. Glaciol., 35, 45-51, https://doi.org/10.3189/172756402781817176, 2002.

Nicholls, K., Corr, H., Stewart, C., Lok, L., Brennan, P., and Vaughan, D.: A ground-based radar for measuring vertical strain rates and time-varying basal melt rates in ice sheets and shelves, J. Glaciol., 61, 1079-1087, 2015.

Nicolas, J. P. and Bromwich, D. H.: Climate of West Antarctica and Influence of Marine Air Intrusions, J. Climate, 24, 49-67, https://doi.org/10.1175/2010JCLI3522.1, 2011.

Nishio, F., Furukawa, T., Hashida, G., Igarashi, M., Kameda, T., Kohno, M., Motoyama, H., Naoki, K., Satow, K., Suzuki, K., Morimasa, T., Toyama, Y., Yamada, T., and Watanabe, O.: Annual-layer determinations and 167 year records of past climate of $\mathrm{H} 72$ ice core in east Dronning Maud Land, Antarctica, Ann. Glaciol., 35, 471-479, 2002.

Noone, D., Turner, J., and Mulvaney, R.: Atmospheric signals and characteristics of accumulation in Dronning Maud Land, Antarctica, J. Geophys. Res., 104, 19191-19211, 1999.

Nye, J.: Correction factor for the accumulation measured by the thickness of the annual layers in an ice sheet, J. Glaciol., 4, 785$788,1963$.

Oerter, H., Graf, W., Wilhelms, F., Minikin, A., and Miller, H.: Accumulation studies on Amundsenisen, Dronning Maud Land, by means of tritium, DEP and stable isotope measurements: first results from the 1995/96 and 1996/97 field seasons, Ann. Glaciol., 29, 1-9, 1999.

Oerter, H., Wilhelms, F., Jung-Rothenhäusler, F., Göktas, F., Miller, H., Graf, W., and Sommer, S.: Accumulation rates in Dronning Maud Land, Antarctica, as revealed by dielectric-profiling measurements of shallow firn cores, Ann. Glaciol., 30, 27-34, 2000.

Palerme, C., Genthon, C., Claud, C., Kay, J. E., Wood, N. B., and L'Ecuyer, T.: Evaluation of current and projected Antarctic precipitation in CMIP5 models, Clim. Dynam., 48, 225-239, https://doi.org/10.1007/s00382-016-3071-1, 2017.
Pasteur, E. C. and Mulvaney, R.: Migration of methane sulphonate in Antarctic firn and ice, J. Geophys. Res., 105, 11525-11534, https://doi.org/10.1029/2000JD900006, 2000.

Philippe, M., Tison, J.-L., Fjøsne, K., Hubbard, B., Kjær, H. A., Lenaerts, J. T. M., Drews, R., Sheldon, S. G., De Bondt, K., Claeys, P., and Pattyn, F.: Ice core evidence for a 20th century increase in surface mass balance in coastal Dronning Maud Land, East Antarctica, The Cryosphere, 10, 2501-2516, https://doi.org/10.5194/tc-10-2501-2016, 2016.

Porter, S. E., Parkinson, C. L., and Mosley-Thompson, E.: Bellingshausen Sea ice extent recorded in an Antarctic Peninsula ice core, J. Geophys. Res.-Atmos., 121, 13886-13900, https://doi.org/10.1002/2016JD025626, 2016.

Raphael, M. N.: The influence of atmospheric zonal wave three on Antarctic sea ice variability, J. Geophys. Res., 112, D12112, https://doi.org/10.1029/2006JD007852, 2007.

Raphael, M. N., Marshall, G., Turner, J., Fogt, R., Schneider, D., Dixon, D., Hosking, J., Jones, J., and Hobbs, W.: The Amundsen Sea low: Variability, change, and impact on Antarctic climate, B. Am. Meteorol. Soc., 97, 111-121, https://doi.org/10.1175/BAMS-D-14-00018.1, 2016.

Renwick, J. A.: Persistent Positive Anomalies in the Southern Hemisphere Circulation, Mon. Weather Rev., 133, 977-988, https://doi.org/10.1175/mwr2900.1, 2005.

Reusch, D. B., Mayewski, P. A., Whitlow, S. I., Pittalwala, I. I., and Twickler, M. S.: Spatial variability of climate and past atmospheric circulation patterns from central West Antarctic glaciochemistry, J. Geophys. Res., 104, 5985-6001, https://doi.org/10.1029/1998JD200056, 1999.

Rignot, E., Velicogna, I., van den Broeke, M. R., Monaghan, A., and Lenaerts, J.: Acceleration of the contribution of the Greenland and Antarctic ice sheets to sea level rise, Geophys. Res. Lett., 38, L05503, https://doi.org/10.1029/2011GL046583, 2011.

Roberts, J., Plummer, C., Vance, T., van Ommen, T., Moy, A., Poynter, S., Treverrow, A., Curran, M., and George, S.: A 2000-year annual record of snow accumulation rates for Law Dome, East Antarctica, Clim. Past, 11, 697-707, https://doi.org/10.5194/cp11-697-2015, 2015.

Rotschky, G., Holmlund, P., Isaksson, E., Mulvaney, R., Oerter, H., Van den Broeke, M. R., and Winther, J.-G.: A new surface accumulation map for western Dronning Maud Land, Antarctica, from interpolation of point measurements, J. Glaciol., 53, 385398, 2007.

Scarchilli, C., Frezzotti, M., and Ruite, P. M.: Snow precipitations at four ice cores sites in East Antarctica: provenance, seasonality and blocking factors, Clim. Dynam., 37, 2107-2125, https://doi.org/10.1007/s00382-010-0946-4, 2011.

Schlosser, E.: Effects Of Seasonal Variability Of Accumulation On Yearly Mean Delta-O-18 Values In Antarctic Snow, J. Glaciol., 45, 463-468, 1999.

Schlosser, E., Duda, M. G., Powers, J. G, and Manning, K. W.: The precipitation regime of Dronning Maud Land, Antarctica, derived from AMPS (Antarctic Mesoscale Prediction System) Archive Data, J. Geophys. Res., 113, D24108, https://doi.org/10.1029/2008JD009968, 2008.

Schlosser, E., Powers, J. G., Duda, M. G., Manning, K. W., Reijmer, C. H., and Van den Broeke, M.: An extreme precipitation event in Dronning Maud Land, Antarctica - a case study using AMPS (Antarctic Mesoscale Prediction System) archive 
data, Polar Res., 29, 330-344, https://doi.org/10.1111/j.17518369.2010.00164.x, 2010a.

Schlosser, E., Manning, K. W., Powers, J. G., Duda, M. G., Birnbaum, G., and Fujita, K.: Characteristics of high-precipitation events in Dronning Maud Land, Antarctica, J. Geophys. Res., 115, D14107, https://doi.org/10.1029/2009JD013410, 2010 b.

Schlosser, E., Powers, J. G., Duda, M. G., and Manning, K. W.: Interaction between Antarctic sea ice and synoptic activity in the circumpolar trough - implications for ice core interpretation, Ann. Glaciol., 52, 9-17, 2011.

Schlosser, E., Anschütz, H., Isaksson, E., Martma, T., Divine, D., and Nøst, O.-A.: Surface mass balance and stable oxygen isotope ratios from shallow firn cores on Fimbulisen, East Antarctica, Ann. Glaciol., 53, 70-78, https://doi.org/10.3189/2012AoG60A102, 2012.

Schlosser, E., Anschütz, H., Divine, D., Martma, T., Sinisalo, A., Altnau, S., Isaksson, E.: Recent climate tendencies on an East Antarctic ice shelf inferred from a shallow firn core network, J. Geophysic. Res., 119, 6549-6562, https://doi.org/10.1002/2013JD020818, 2014.

Schlosser, E., Stenni, B., Valt, M., Cagnati, A., Powers, J. G., Manning, K. W., Raphael, M., and Duda, M. G.: Precipitation and synoptic regime in two extreme years 2009 and 2010 at Dome C, Antarctica - implications for ice core interpretation, Atmos. Chem. Phys., 16, 4757-4770, https://doi.org/10.5194/acp16-4757-2016, 2016.

Shepherd, A., Ivins, E. R., A, G., Barletta, V. R., Bentley, M. J., Bettadpur, S., Briggs, K. H., Bromwich, D. H., Forsberg, R., Galin, N., Horwath, M., Jacobs, S., Joughin, I., King, M. A., Lenaerts, J. T. M., Li, J., Ligtenberg, S. R. M., Luckman, A., Luthcke, S. B., McMillan, M., Meister, R., Milne, G., Mouginot, J., Muir, A., Nicolas, J. P., Paden, J., Payne, A. J., Pritchard, H., Rignot, E., Rott, H., Sørensen, L. S., Scambos, T. A., Scheuchl, B., Schrama, E. J. O., Smith, B., Sundal, A. V., van Angelen, J. H., van de Berg, W. J., van den Broeke, M. R., Vaughan, D. G., Velicogna, I., Wahr, J., Whitehouse, P. L., Wingham, D. J., Yi, D., Young, D., and Zwally, H. J.: A reconciled estimate of ice-sheet mass balance, Science, 338, 1183-1189, https://doi.org/10.1126/science.1228102, 2012.

Simmons, A., Uppala, S., Dee, D., and Kobayashi, S.: ERA-Interim: New ECMWF reanalysis products from 1989 onwards, ECMWF Newsletter No. 110, Reading, UK, 2007.

Sinclair, K. E., Bertler, N. A. N., and Trompetter, W. J.: Synoptic controls on precipitation pathways and snow delivery to high-accumulation ice core sites in the Ross Sea region, Antarctica, J. Geophys. Res., 115, D22112, https://doi.org/10.1029/2010jd014383, 2010.

Sinclair, K. E., Bertler, N. A., Trompetter, W. J., and Baisden, W. T.: Seasonality of airmass pathways to Coastal Antarctica: Ramifications of interpreting high-resolution ice core records, J. Climate, 26, 2065-2076, 2013.

Sinisalo, A., Anschütz, H., Aasen, A. T., Langley, K., von Deschwanden, A., Kohler, J., Matsuoka, K., Hamran, S.E., Øyan, M.-J., Schlosser, E., Hagen, J. O., Nøst, O. A., and Isaksson, E.: Surface mass balance on Fimbul ice shelf, East Antarctica: Comparison of field measurements and largescale studies, J. Geophys. Res.-Atmos., 118, 11625-11635, https://doi.org/10.1002/jgrd.50875, 2013.
Smith, R. J.: Use and Misuse of the Reduced Major Axis for LineFitting, Am. J. Phys. Anthropol., 140, 476-486, 2009.

Sodemann, H. and Stohl, A.: Asymmetries in the moisture origin of Antarctic precipitation, Geophys. Res. Lett., 36, L22803, https://doi.org/10.1029/2009GL040242, 2009.

Sommer, S., Appenzeller, C., Rothlisberger, R., Hutterli, M. A., Stauffer, B., Wagenbach, D., Oerter, H., Wilhelms, F., Miller, H., and Mulvaney, R.: Glacio-chemical study spanning the past $2 \mathrm{kyr}$ on three ice cores from Dronning Maud Land, Antarctica 1. Annually resolved accumulation rates, J. Geophys. Res., 105, 29411-29421, https://doi.org/10.1029/2000JD900449, 2000.

Stenni, B., Caprioli, R., Cimmino, L., Cremisini, C., Flora, O., Gragnani, R., Longinelli, A., Maggi, V., and Torcini, S.: 200 years of isotope and chemical records in a firn core from Hercules Neve, northern Victoria Land, Antarctica, Ann. Glaciol., 29, 106-112, 1999.

Stenni, B., Proposito, M., Gragnani, R., Flora, O., Jouzel, J., Falourd, S., and Frezzotti, M.: Eight centuries of volcanic signal and climate change at Talos Dome (East Antarctica), J. Geophys. Res., 107, 4076, https://doi.org/10.1029/2000JD000317, 2002.

Stenni, B., Scarchilli, C., Masson-Delmotte, V., Schlosser, E., Ciardini, V., Dreossi, G., Grigioni, P., Bonazza, M., Cagnati, A., Karlicek, D., Risi, C., Udisti, R., and Valt, M.: Threeyear monitoring of stable isotopes of precipitation at Concordia Station, East Antarctica, The Cryosphere, 10, 2415-2428, https://doi.org/10.5194/tc-10-2415-2016, 2016.

Thomas, E.: Antarctic regional snow accumulation composites over the past 1000 years, Polar Data Centre, Natural Environment Research Council, UK, https://doi.org/10.5285/c4ecfe25-12f2453b-ad19-49a19e90ee32, 2017.

Thomas, E. R. and Abram, N.: Ice core reconstruction of sea ice change in the Amundsen-Ross Seas since 1702 AD, Geophys. Res. Lett., 43, 5309-5317, https://doi.org/10.1002/2016GL068130, 2016.

Thomas, E. R. and Bracegirdle, T. J.: Improving ice core interpretation using in situ and reanalysis data, J. Geophys. Res., 114, D20116, https://doi.org/10.1029/2009JD012263, 2009.

Thomas, E. R. and Bracegirdle, T. J.: Precipitation pathways for five new ice core sites in Ellsworth Land, West Antarctica, Clim. Dynam., 44, 2067-2078, https://doi.org/10.1007/s00382-014-22136,2015 .

Thomas, E. R., Marshall, G. J., and McConnell, J. R.: A doubling in snow accumulation in the western Antarctic Peninsula since 1850, Geophys. Res. Lett., 35, L01706, https://doi.org/10.1029/2007GL032529, 2008.

Thomas, E. R., Hosking, J. S., Tuckwell, R. R., Warren, R. A., and Ludlow, E. C.: Twentieth century increase in snowfall in coastal West Antarctica, Geophys. Res. Lett., 42, 9387-9393, https://doi.org/10.1002/2015GL065750, 2015.

Thompson, L. G., Peel, D. A., Mosley-Thompson, E., Mulvaney, R., Dai, J., Lin, P. N., Davis, M. E., and Raymond, C. F.: Climate change since AD 1510 on Dyer Plateau, Antarctic Peninsula: Evidence for recent climate change, Ann. Glaciol., 20, 420-426, 1994.

Tsukernik, M. and Lynch, A. H.: Atmospheric meridional moisture flux over the southern ocean: A story of the Amundsen Sea, J. Climate, 26, 8055-8064, 2013.

Tuohy, A., Bertler, N., Neff, P., Edwards, R., Emanuelsson, D., Beers, T., and Mayewski, P.: Transport and 
deposition of heavy metals in the Ross Sea Region, Antarctica, J. Geophys. Res.-Atmos., 120, 10996-11011, https://doi.org/10.1002/2015jd023293, 2015.

Turner, J., Comiso, J. C., Marshall, G. J., Lachlan-Cope, T. A., Bracegirdle, T., Maksym, T., Meredith, M. P., Wang, Z., and Orr, A.: Non-annular atmospheric circulation change induced by stratospheric ozone depletion and its role in the recent increase of Antarctic sea ice extent, Geophys. Res. Lett., 36, L08502, https://doi.org/10.1029/2009GL037524, 2009.

Turner, J., Phillips, T., Hosking, J. S., Marshall, G. J., and Orr, A.: The Amundsen Sea low, Int. J. Climatol., 33, 1818-1829, 2013.

Urbini, S., Frezzotti, M., Gandolfi, S., Vincent, C., Scarchilli, C., Vittuari, L., and Fily, M.: Historical behaviour of Dome C and Talos Dome (East Antarctica) revealed by snow accumulation and ice velocity measurements, Global Planet. Change, 60, 576588, https://doi.org/10.1016/j.gloplacha.2007.08.002, 2008.

Vallelonga, P., Maffezzoli, N., Moy, A. D., Curran, M. A. J., Vance, T. R., Edwards, R., Hughes, G., Barker, E., Spreen, G., SaizLopez, A., Corella, J. P., Cuevas, C. A., and Spolaor, A.: Sea-icerelated halogen enrichment at Law Dome, coastal East Antarctica, Clim. Past, 13, 171-184, https://doi.org/10.5194/cp-13-1712017, 2017.

Vance, T., Roberts, J., Plummer, C., Kiem, A., and van Ommen, T.: Interdecadal Pacific variability and Eastern Australian megadroughts over the last millennium, Geophys. Res. Lett., 42, 129-137, https://doi.org/10.1002/2014GL062447, 2015.

van de Berg, W. J. and Medley, B.: Brief Communication: Upper-air relaxation in RACMO2 significantly improves modelled interannual surface mass balance variability in Antarctica, The Cryosphere, 10, 459-463, https://doi.org/10.5194/tc10-459-2016, 2016.

Van de Berg, W. J., Van den Broeke, M. R., Reijmer, C. H., and Van Meijgaard, E.: Characteristics of the Antarctic surface mass balance, 1958-2002, using a regional atmospheric climate model, Ann. Glaciol., 41, 97-104, https://doi.org/10.3189/172756405781813302, 2005.

van de Berg, W. J., van den Broeke, M. R., Reijmer, C., and Van Meijgaard, E.: Reassessment of the Antarctic surface mass balance using calibrated output of a regional atmospheric climate model, J. Geophys. Res., 111, D11104, https://doi.org/10.1029/2005JD006495, 2006.

van Ommen, T. and Morgan, V.: Snowfall increase in coastal East Antarctica linked with southwest Western Australian drought, Nat. Geosci., 3, 267-272, 2010.

Van Wessem, J. M., Reijmer, C. H., Morlighem, M., Mouginot, J., Rignot, E., Medley, B., and Van Meijgaard, E.: Improved representation of East Antarctic surface mass balance in a regional atmospheric climate model, J. Glaciol., 60, 761-770, https://doi.org/10.3189/2014JoG14J051, 2014.

van Wessem, J. M., Ligtenberg, S. R. M., Reijmer, C. H., van de Berg, W. J., van den Broeke, M. R., Barrand, N. E., Thomas, E. R., Turner, J., Wuite, J., Scambos, T. A., and van Meijgaard, E.: The modelled surface mass balance of the Antarctic Peninsula at $5.5 \mathrm{~km}$ horizontal resolution, The Cryosphere, 10, 271-285, https://doi.org/10.5194/tc-10-271-2016, 2016.
Vega, C. P., Schlosser, E., Divine, D. V., Kohler, J., Martma, T., Eichler, A., Schwikowski, M., and Isaksson, E.: Surface mass balance and water stable isotopes derived from firn cores on three ice rises, Fimbul Ice Shelf, Antarctica, The Cryosphere, 10, 2763-2777, https://doi.org/10.5194/tc-10-2763-2016, 2016.

Velicogna, I. and Wahr, J.: Measurements of time-variable gravity show mass loss in Antarctica, Science, 311, 1754-1756, https://doi.org/10.1126/science.1123785, 2006.

Walden, W., Warren, S. G., and Tuttle, E.: Atmospheric ice crystals over hte Antarctic Plateau in winter, J. Appl. Meteorol., 42, 1391-1405, https://doi.org/10.1175/1520 0450(2003)042<1391:AICOTA>2.0.CO;2, 2003.

Wang, Y., Hou, S., Sun, W., Lenaerts, J. T., van den Broeke, M. R., and van Wessem, J. M.: Recent surface mass balance from Syowa Station to Dome F, East Antarctica: comparison of field observations, atmospheric reanalyses, and a regional atmospheric climate model, Clim. Dynam., 45, 2885-2899, 2015.

Wang, Y., Ding, M., van Wessem, J., Schlosser, E., Altnau, S., van den Broeke, M., Lenaerts, J., Thomas, E., Isaksson, E., Wang, J., and Sun, W.: A Comparison of Antarctic Ice Sheet Surface Mass Balance from Atmospheric Climate Models and In Situ Observations, J. Climate, 29, 5317-5337, https://doi.org/10.1175/JCLID-15-0642.1, 2016.

Winstrup, M., Vallelonga, P., Kjær, H. A., Fudge, T. J., Lee, J. E., Riis, M. H., Edwards, R., Bertler, N. A. N., Blunier, T., Brook, E. J., Buizert, C., Ciobanu, G., Conway, H., Dahl-Jensen, D., Ellis, A., Emanuelsson, B. D., Keller, E. D., Kurbatov, A., Mayewski, P., Neff, P. D., Pyne, R., Simonsen, M. F., Svensson, A., Tuohy, A., Waddington, E., and Wheatley, S.: A 2700year annual timescale and accumulation history for an ice core from Roosevelt Island, West Antarctica, Clim. Past Discuss., https://doi.org/10.5194/cp-2017-101, in review, 2017.

Wouters, B., Bamber, J. L., van den Broeke, M. R., Lenaerts, J. T. M., and Sasgen, I.: Limits in detecting acceleration of ice sheet mass loss due to climate variability, Nat. Geosci., 6, 613-616, https://doi.org/10.1038/ngeo1874, 2013.

Xiao, C., Allison, I., Ren, J. W., Qin, D. H., Zhang, M. J., and Li, Z. Q.: Meteorological and glaciological evidence for different climatic variations on the east and west side of the Lambert Glacier basin, Antarctica, Ann. Glaciol., 39, 188-194, 2004.

Yuan, X. and Martinson, D. G.: The Antarctic dipole and its predictability, Geophys. Res. Lett., 28, 3609-3612, https://doi.org/10.1029/2001GL012969, 2001.

Zwally, H., Li, J., Robbins, J., Saba, J., Yi, D., and Brenner, A.: Mass gains of the Antarctic ice sheet exceed losses, J. Glaciol. 61, 1019-1036, https://doi.org/10.3189/2015JoG15J071, 2015. 